\title{
Cancer Cell Resistance Against the Clinically Investigated Thiosemicarbazone COTI-2 Is Based on Formation of Intracellular Copper Complex Glutathione Adducts and ABCC1-Mediated Efflux
}

\author{
Julia H. Bormio Nunes, " Sonja Hager," Marlene Mathuber, Vivien Pósa, Alexander Roller, Éva A. Enyedy,
} Alessia Stefanelli, Walter Berger, Bernhard K. Keppler, Petra Heffeter, ${ }^{*}$ and Christian R. Kowol*

Cite This: J. Med. Chem. 2020, 63, 13719-13732

Read Online

ACCESS | Lلll Metrics \& More | 回 Article Recommendations | st Supporting Information

ABSTRACT: COTI-2 is a novel anticancer thiosemicarbazone in phase I clinical trial. However, the effects of metal complexation (a main characteristic of thiosemicarbazones) and acquired resistance mechanisms are widely unknown. Therefore, in this study, the copper and iron complexes of COTI-2 were synthesized and evaluated for their anticancer activity and impact on drug resistance in comparison to metal-free thiosemicarbazones. Investigations using Triapine-resistant SW480/Tria and newly established COTI2-resistant SW480/Coti cells revealed distinct structure-activity

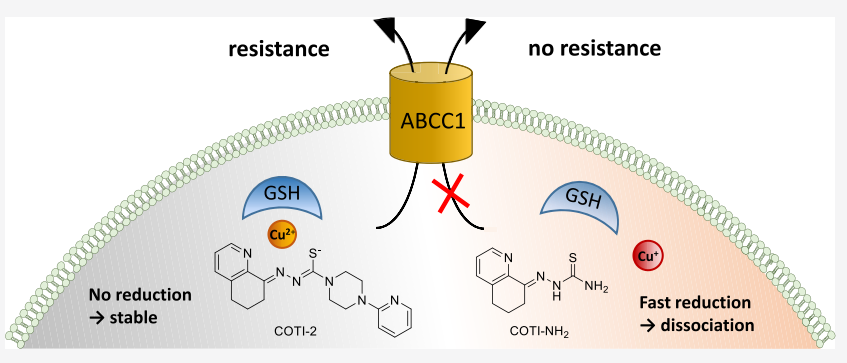
relationships. SW480/Coti cells were found to overexpress $\mathrm{ABCC} 1$, and COTI-2 being a substrate for this efflux pump. This was unexpected, as ABCC1 has strong selectivity for glutathione adducts. The recognition by $\mathrm{ABCC} 1$ could be explained by the reduction kinetics of a ternary Cu-COTI-2 complex with glutathione. Thus, only thiosemicarbazones forming stable, nonreducible copper(II)-glutathione adducts are recognized and, in turn, effluxed by $\mathrm{ABCC} 1$. This reveals a crucial connection between copper complex chemistry, glutathione interaction, and the resistance profile of clinically relevant thiosemicarbazones.

\section{INTRODUCTION}

$\alpha-N$-Heterocyclic thiosemicarbazones represent an important class of metal-chelating agents, owing to their N,N,S-donor ligand set. ${ }^{1}$ Both, the free ligands and their metal complexes (e.g., $\mathrm{Cu}, \mathrm{Fe}, \mathrm{Zn}, \mathrm{Ga}, \mathrm{Ru}$, etc.) have been widely investigated as antibacterial, antiviral, and anticancer agents. ${ }^{2}$ Concerning their antitumor properties, they were originally developed as iron chelators. However, they are not just iron chelators, such as, e.g., desferrioxamine (DFO) that sequesters mainly extracellular iron due to its strong iron(III)-binding ability. Instead, thiosemicarbazones are considered as "iron-interacting” drugs influencing diverse iron-dependent biological pathways due to their ability to form highly stable complexes with both iron(II) and iron(III) ions. ${ }^{3,4}$ Also, the interaction with cellular copper ions has been associated with their mechanism of action, at least for a part of the known anticancer thiosemicarbazones. ${ }^{5,6}$

With regard to clinical development, 3-aminopyridine-2carboxaldehyde thiosemicarbazone (Triapine, Scheme 1) is the most prominent representative. Triapine, whose main target is considered to be the iron-dependent ribonucleotide reductase, ${ }^{3,4}$ has been evaluated in multiple phase I and II clinical trials against a number of different cancer types. ${ }^{7}$ Recently, also, a clinical phase III study was initiated with Triapine in combination with cisplatin and radiation therapy in cervical or vaginal cancer patients (study number NCT02595879,
Scheme 1. Chemical Structures of the Clinically Investigated Triapine, $\mathrm{DpC}$, and COTI-2 as well as the Terminally Unsubstituted Derivative COTI- $\mathrm{NH}_{2}$<smiles>NC(=S)N/N=C/c1ncccc1N</smiles><smiles>CN(C(=S)NN=C(c1ccccn1)c1ccccn1)C1CCCCC1</smiles><smiles>CC(C)=O</smiles><smiles>NC(=O)NN=C1CCCc2cccnc21</smiles>

clinicaltrials.gov). Based on the clinical success of Triapine, there is also interest to develop other thiosemicarbazones with improved anticancer activity, novel modes of action, and

Received: July 22, 2020

Published: November 16, 2020 
different drug resistance profiles. Thus, several reports were published recognizing that $\alpha$-N-heterocyclic thiosemicarbazones with terminally disubstituted $\mathrm{NH}_{2}$ groups display highly increased anticancer activity in the nanomolar range in cell culture. $^{8,9}$ Noteworthy, this thiosemicarbazone subclass is characterized by a higher copper(II) complex stability and additional modes of action such as induction of paraptotic cell death. ${ }^{6,10}$ One of these thiosemicarbazones, namely, di-2pyridylketone 4-cyclohexyl-4-methyl-3-thiosemicarbazone (DpC; Scheme 1), entered a phase I clinical trial in 2016 (study number NCT02688101). ${ }^{11,12}$ At the same time, another highly active but structurally more divergent thiosemicarbazone, 4-(pyridine-2-yl)- $N$-([(8E)-5,6,7,8-tetrahydroquinolin-8ylidene]amino)piperazine-1-carbothioamide, also known as COTI-2 (Scheme 1), was developed by Cotinga Pharmaceuticals as a third-generation representative. COTI- 2 has entered a phase $\mathrm{Ib} / \mathrm{IIa}$ clinical trial for the treatment of gynecologic malignancies in 2015 (study number NCT02433626). ${ }^{13}$ Biological investigations revealed that COTI-2 possesses high efficacy against multiple cancers both in vitro (also in the nanomolar range) and in vivo. Moreover, COTI-2 seems to differ in its mode of action from other thiosemicarbazones, as it has been reported to restore the functionality (and thus tumor suppressor activity) of mutated p53. ${ }^{14,15}$

However, until now, no studies on the interaction of COTI2 with cellular metal ions, such as iron and copper, have been performed. Additionally, it is unknown whether the anticancer activity of COTI-2 is influenced by acquired drug resistance to other thiosemicarbazones. This is of interest, as our previous investigations revealed that small structural changes, which are associated with a shift into the nanomolar range of activity, also result in a distinctly altered drug resistance profile. In more detail, while Triapine was found to be a weak substrate for the $\mathrm{ABC}$ transporter efflux protein P-glycoprotein (P-gp, ABCB 1$),{ }^{16}$ terminally dimethylated $\alpha-N$-heterocyclic thiosemicarbazones are transported by the multidrug resistance protein 1 (MRP1, ABCC1) but not by $\mathrm{ABCB} 1 .^{17}$ This is of interest, as $\mathrm{ABCC} 1$ is an efflux pump, which usually transports drugs in a glutathione (GSH)-dependent manner (e.g., in the form of GSH adducts or by a co-transport mechanism). ${ }^{18-20}$ However, although GSH depletion strongly enhanced the anticancer activity of these previously tested nanomolar-active derivatives, no GSH conjugate formation by incubation with GSH-S-transferase could be observed. ${ }^{17}$

The aim of this study was, on the one hand, to synthesize the first metal complexes of COTI-2 with the biologically relevant ions, iron(III) and copper(II), together with the Triapine-like nonsubstituted $\left(\mathrm{COTI}-\mathrm{NH}_{2}\right)$ representative as a reference (Scheme 1). On the other hand, these compounds were subsequently tested for their biological activity in chemosensitive and thiosemicarbazone-resistant SW480 cells, including the newly generated COTI-2-resistant SW480/Coti model. Based on these studies, we could show that the resistance of SW480/Coti cells is due to overexpression of $\mathrm{ABCC} 1$ and strongly associated with the thiosemicarbazone copper complex chemistry. In more detail, in the presence of copper(II), COTI-2 forms stable, nonreducible ternary GSH copper(II) complexes, which are, in turn, substrates for ABCC1. This indicates that the specific copper chemistry of thiosemicarbazones not only affects their mode of action but also their resistance profile.

\section{RESULTS AND DISCUSSION}

Syntheses and Chemical Characterization. COTI-2 was obtained in a three-step procedure, ${ }^{21}$ starting with the piperazine insertion to thiocarbonyldiimidazole (Supporting Information, Scheme S1). Reaction with hydrazine hydrate generated the respective COTI-2 thiosemicarbazide, which was condensed with 6,7-dihydroquinoline-8-one yielding COTI-2. COTI- $\mathrm{NH}_{2}$ was obtained by condensation of the ketone with the appropriate commercially available $\mathrm{N}^{4}-\mathrm{NH}_{2}$ thiosemicarbazide. $^{22}$

The NMR spectroscopy analysis revealed that the two compounds are present in a different number of isomers, a phenomenon well-known for thiosemicarbazones. ${ }^{23,24}$ Three different types of isomers are distinguished: (i) the Econfiguration regarding the $\mathrm{C}=\mathrm{N}$ bond, (ii) the respective Z-isomer, and (iii) a zwitterionic form called $\mathrm{E}^{\prime}$-isomer (structures for COTI-2 see Scheme 2). The ${ }^{1} \mathrm{H}$ NMR

Scheme 2. Different Possible Isomers of COTI-2. The Zand $\mathrm{E}^{\prime}$-Isomers Have Strongly Downfield Shifted NH Rresonance NMR Signals due to the Presence of Intramolecular Hydrogen Bonds

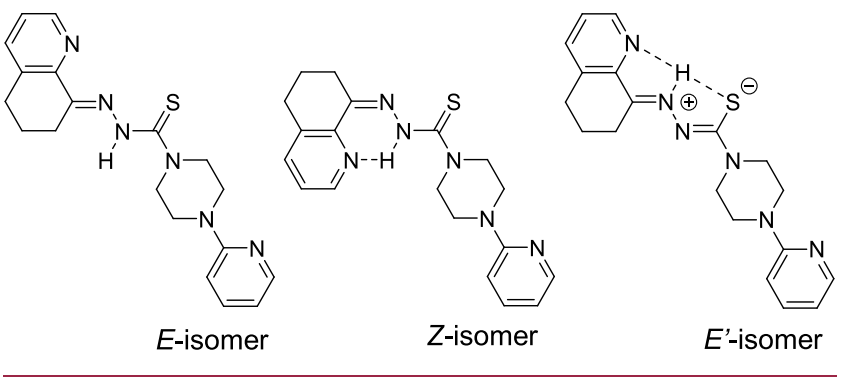

spectrum of COTI-NH $\mathrm{N}_{2}$ in DMSO- $d_{6}$ showed only one type of isomer, whereas in case of COTI-2, two isomers could be observed. Interestingly, for both compounds and all isomers, the chemical shifts of the hydrazonic NH protons were in the range of $14.3-15.5 \mathrm{ppm}$. Consequently, we assigned them to the Z- and $\mathrm{E}^{\prime}$-isomers, which both possess intramolecular hydrogen bonds, explaining the strong downfield shift. In contrast, the E-isomer (without a hydrogen bond) usually has an $\mathrm{NH}$ signal resonance at around $10-11 \mathrm{ppm} .{ }^{23,24}$ Recently, we could separate the E-and Z-isomers of a Triapine derivative $^{9}$ and investigated their cytotoxicities; however, no significant differences were observed. Therefore, we do not expect an influence of the different isomers on the biological characteristics of the COTI-2 compounds.

The calculated $\log P$ values ${ }^{25}$ for COTI-2 and COTI-NH are +2.89 and +1.43 , respectively, indicating high lipophilicity, especially for COTI-2.

The metal complexes of COTI- 2 were obtained by reaction with the respective metal salts. For the iron(III) complex (FeCOTI-2), the reaction of COTI-2 with $\mathrm{Fe}\left(\mathrm{NO}_{3}\right)_{3} \cdot 9 \mathrm{H}_{2} \mathrm{O}$ in methanol resulted in a complex with 1:2 metal-to-ligand ratio, with two neutral ligands and consequently a +3 charge $\left[\mathrm{Fe}(\mathrm{HL})_{2}\right]\left(\mathrm{NO}_{3}\right)_{3} \quad(\mathrm{HL}=\mathrm{COTI}-2$, Scheme 3). This composition is different from what is usually observed for the iron(III) complex with Triapine or similar thiosemicarbazones, in which both ligands are deprotonated and the complex has a +1 charge $\left(\left[\mathrm{Fe}(\mathrm{L})_{2}\right]^{+}\right){ }^{8,26,27}$ For the copper(II) complex $(\mathrm{Cu}-\mathrm{COTI}-2)$, the ligand was reacted with $\mathrm{CuCl}_{2} \cdot 2 \mathrm{H}_{2} \mathrm{O}$, yielding a complex with 1:1 metal-to-ligand ratio, with a neutral thiosemicarbazone and two chlorido ligands 
Scheme 3. Chemical Structure of the Iron(III) and Copper(II) Complex of COTI-2

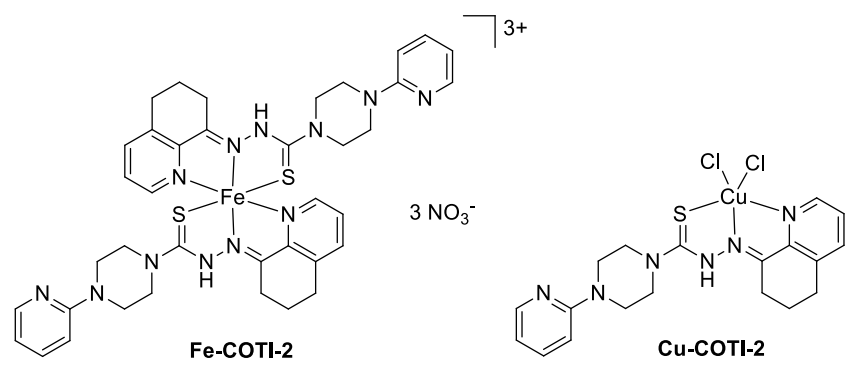

( $\left[\mathrm{Cu}(\mathrm{HL}) \mathrm{Cl}_{2}\right]$, Scheme 3$)$. This composition was also observed for, e.g., the Triapine copper(II) complex. ${ }^{28}$ All proposed structures were confirmed by mass spectrometry and elemental analyses.

X-Ray Crystal Structures. For COTI-2 and Cu-COTI-2, crystals were obtained by slow evaporation of the mother liquor, which were suitable for analysis by single-crystal X-ray diffraction. COTI- 2 crystalized in the triclinic $P \overline{1}$ space group. Selected bond distances and angles are quoted in the legend of Figure 1A. The COTI-2 crystal adopted the zwitterionic E'isomeric form (in agreement with one isomer observed in the NMR spectrum) in which an intramolecular hydrogen bond is observed between N1, S1, and the hydrogen H-N2. Notably, in this case, N2 is protonated and not N3, as usually assumed and drawn in the typical thiosemicarbazone structures (Scheme 1). The piperazine moiety is in a chair configuration, while the cyclohexyl of the tetrahydroquinoline moiety is in a half-chair configuration. Comparing the crystal structure of COTI- 2 with the crystal structure of COTI- $\mathrm{NH}_{2}$ reported in literature, ${ }^{29}$ COTI- $\mathrm{NH}_{2}$ crystalized in the $P 21 / n$ space group and adopted the $\mathrm{Z}$-isomeric form. Most bond angles and distances are comparable. However, a major difference is the length of the $\mathrm{C}-\mathrm{S}$ bond, which is shorter in the case of COTI$\mathrm{NH}_{2}(1.683 \AA)$ compared to COTI-2 (1.717 $\left.\AA\right)$. This can nicely be explained by the thione form of the sulfur atom in the case of COTI-NH $\mathrm{N}_{2}$ and the zwitterionic thiol for COTI-2.

For Cu-COTI-2, two different crystal structures were obtained, one deprotonated (from the synthesis without $\mathrm{HCl}$ ), named $\mathrm{Cu}-\mathrm{COTI}-2 \mathrm{a}$, and the other one protonated (from the synthesis with $\mathrm{HCl}$ ), named $\mathrm{Cu}-\mathrm{COTI}-2 \mathrm{~b}$. Notably, both crystal structures differ from the bulk material, where COTI-2 is neutral (HL) with two chlorido ligands for each copper center (Scheme 3). Two bridging chlorido ligands are observed between the copper(II) centers for both structures (Figure 1B,C), a structural mode which has already been reported for other copper(II) thiosemicarbazone complexes. $^{30-32}$ In both crystal structures, the copper(II) ions have a coordination number of five, being in a squarepyramidal geometry, where $\mathrm{N} 1, \mathrm{~N} 2, \mathrm{~S} 1$ and $\mathrm{Cl} 1$ are the base of the pyramid (forming the asymmetric unit of the complex), and the $\mathrm{Cl}^{\prime}$ from another unit is in the axial position (for $\mathrm{Cu}$ COTI-2a, $2.749 \AA$ vs $2.256 \AA$ for Cu-Cl1; for Cu-COTI-2b, $2.720 \AA$ vs $2.245 \AA$ for $\mathrm{Cu}-\mathrm{Cl} 1$ ). Most of the bond lengths and angles are comparable between the deprotonated complex and protonated form (quoted in the legend of Figure 1). However, for example, the $\mathrm{C} 10-\mathrm{S} 1$ bond length of $\mathrm{Cu}-\mathrm{COTI}-2 \mathrm{a}$ at 1.754 $\AA$ is distinctly longer compared to $\mathrm{Cu}-\mathrm{COTI}-2 \mathrm{~b}$ at $1.706 \AA$. This nicely fits to the expected elongated C10-S1 bond of the deprotonated ligand and the greater double-bond character in the case of Cu-COTI-2b due to the protonated N3 (Figure 1).
A

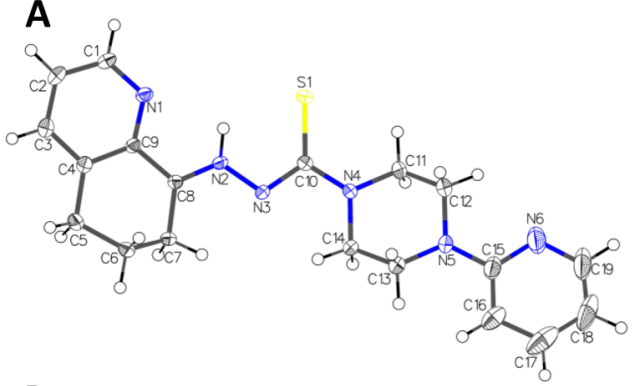

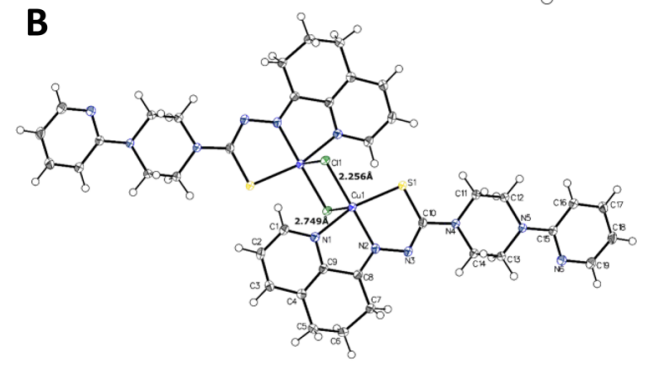

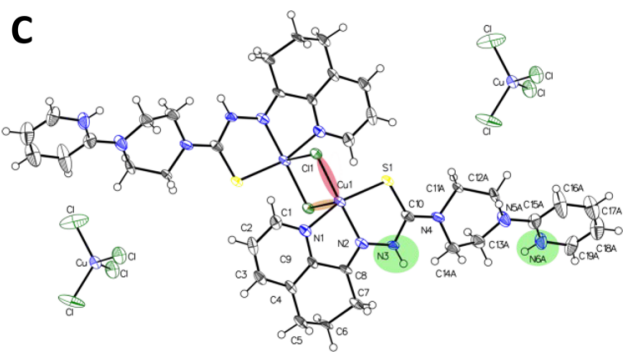

Figure 1. ORTEP plots of (A) COTI-2, (B) Cu-COTI-2a, and (C) $\mathrm{Cu}-\mathrm{COTI}-2 \mathrm{~b}$ with atom numbering. Ellipsoids are drawn at the $50 \%$ probability level. Selected bond lengths $(\AA)$ and bond angles $\left({ }^{\circ}\right)$ for (A) COTI-2 (bond precision for $\mathrm{C}-\mathrm{C}$ single bond is $0.0030 \AA$ ): $\mathrm{C} 8-$ N2 1.300(9), N2-N3 1.354(3), N3-C10 1.351(8), C10-S 1.717(1), C10-N4 1.361(4); N1-C9-C8 116.3, N2-N3-C10 112.0. For (B) $\mathrm{Cu}-\mathrm{COTI}-2 \mathrm{a}$ (bond precision for $\mathrm{C}-\mathrm{C}$ single bond is $0.0030 \AA$ ), two different types of $\mathrm{Cu}-\mathrm{Cl}$ bonds occur: $\mathrm{Cu} 1-\mathrm{Cl1} 2.255(8) \AA$, $\mathrm{Cu} 1-$ $\mathrm{Cl1}^{\prime}(1-\mathrm{X},-\mathrm{Y},-\mathrm{Z}) 2.748(6)$ Å. Further selected bond lengths $(\AA)$ and bond angles $\left(^{\circ}\right)$ : $\mathrm{N} 1-\mathrm{Cu} 2.029(9) \AA \AA \mathrm{N} 2-\mathrm{Cu} 1.961(3), \mathrm{S} 1-\mathrm{Cu}$ 2.268(2) $\AA, \mathrm{Cu} \cdots \mathrm{Cu} 3.52 ; \mathrm{Cl}-\mathrm{Cu} 1-\mathrm{Cl}^{\prime} 91.2, \mathrm{Cl}-\mathrm{Cu}-\mathrm{S} 97.8, \mathrm{~N} 1-$ $\mathrm{Cu}-\mathrm{N} 2$ 80.9, N2-Cu-S 84.2, N1-Cu1-Cl 96.3. For (C) CuCOTI- $2 \mathrm{~b}$ (bond precision for $\mathrm{C}-\mathrm{C}$ single bonds is $0.0121 \AA$ ), the main residue disorder is $39 \%$. The counter ion $\left[\mathrm{CuCl}_{4}\right]^{-2}$ position is shifted, and solvent $\left(\mathrm{H}_{2} \mathrm{O}\right)$ and the disordered second part were omitted for clarity. Two different types of $\mathrm{Cu}-\mathrm{Cl}$ bonds occur: $\mathrm{Cu} 1-$ Cl1 2.245(3) Å (light red shaded) and Cu1-Cl1' (1-X,1-Y,1-Z) $2.719(8) \AA$ (light orange shaded). Green-shaded areas visualize protonated nitrogen positions. Further selected bond lengths $(\AA)$ and bond angles $\left(^{\circ}\right): \mathrm{N} 1-\mathrm{Cu} 2.022(7) \AA, \mathrm{N} 2-\mathrm{Cu} 1.958(8), \mathrm{S} 1-\mathrm{Cu}$ 2.260(7) $\mathrm{A}, \mathrm{Cu} \cdots \mathrm{Cu} 3.42 ; \mathrm{Cl}-\mathrm{Cu} 1-\mathrm{Cl}^{\prime}$ 93.3, $\mathrm{Cl}-\mathrm{Cu}-\mathrm{S}$ 95.8, N1$\mathrm{Cu}-\mathrm{N} 280.5, \mathrm{~N} 2-\mathrm{Cu}-\mathrm{S} 84.8, \mathrm{~N} 1-\mathrm{Cu} 1-\mathrm{Cl} 98.1$.

The influence of the protonated $\mathrm{N} 3$ can be also observed in the $\mathrm{C} 10-\mathrm{N} 3$ bond, which is $1.328 \AA$ for Cu-COTI-2a and $1.376 \AA$ for $\mathrm{Cu}$-COTI-2b. In the crystal structure of Cu-COTI$2 \mathrm{~b}$, two $\left[\mathrm{CuCl}_{4}\right]^{2-}$ counter ions are present, which compensate the +4 charge from $\left[\mathrm{Cu}_{2} \mathrm{Cl}_{2}\left(\mathrm{H}_{2} \mathrm{~L}\right)\right]^{4+}$ (with $\mathrm{H}_{2} \mathrm{~L}=$ protonated COTI-2). Also, conformational differences are observed for the piperazine moiety of the complexes; for $\mathrm{Cu}-\mathrm{COTI}-2 \mathrm{a}$, the piperazine is in a chair-conformation, while for $\mathrm{Cu}-\mathrm{COTI}-2 \mathrm{~b}$, it is in a half-chair conformation (Figure S1). In case of the respective Triapine complex, the binding mode to copper(II) is different, with some intermolecular $\mathrm{Cu}-\mathrm{S}$ bonds forming a 

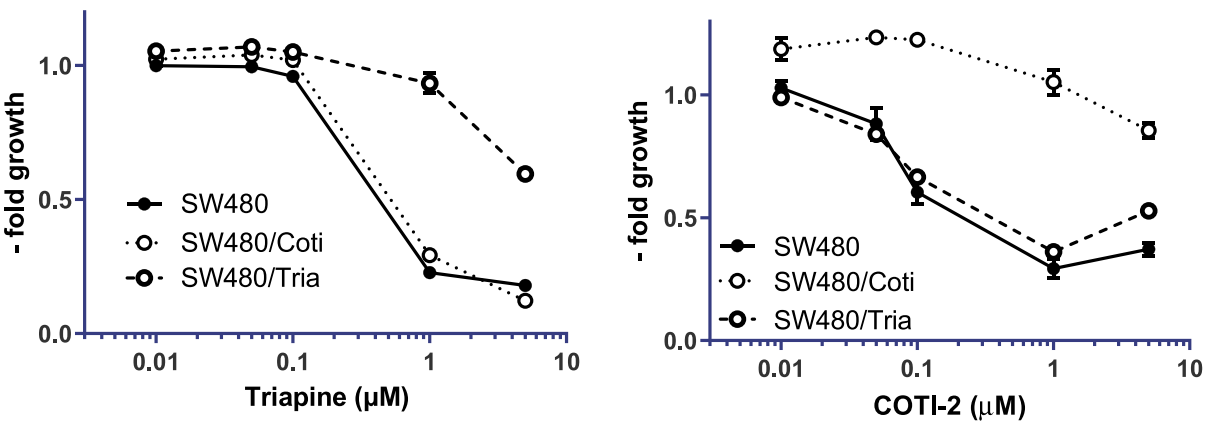

Figure 2. Resistance of SW480/Tria and SW480/Coti cells against Triapine and COTI-2. Anticancer activity of the drugs was tested by the MTT viability assay after $72 \mathrm{~h}$ drug incubation in SW480 vs the resistant sublines. Mean \pm standard deviation (SD) was derived from triplicates of one representative experiment out of three.

Table 1. Anticancer Activity $\left(\mathrm{IC}_{50}\right.$ Values after $72 \mathrm{~h}$ ) of the Indicated Thiosemicarbazones and Metal Complexes in SW480 and Thiosemicarbazone-Resistant SW480/Coti and SW480/Tria Colon Cancer Cells

$\begin{array}{lccccc}\text { compound } & \mathrm{SW}_{80}\left(\mathrm{IC}_{50}, \mu \mathrm{M}\right)^{a} & \mathrm{SW} 480 / \text { Coti }\left(\mathrm{IC}_{50}, \mu \mathrm{M}\right)^{a} & \text { relative resistance } & \mathrm{SW}^{b} 80 / \text { Tria }\left(\mathrm{IC}_{50}, \mu \mathrm{M}\right)^{a} & \text { relative resistance }^{b} \\ \text { COTI-2 } & 0.56 \pm 0.16 & 9.51 \pm 3.11 & 18.9^{*} & 0.41 \pm 0.16 & 0.8^{\text {n.s }} \\ \text { Triapine } & 0.82 \pm 0.18 & 0.81 \pm 0.08 & 1.0^{\text {n.s. }} & >50^{c} & >61 \\ \text { COTI-NH } & 7.85 \pm 0.92 & 4.39 \pm 0.56 & 0.6^{* * * *} & >20 & >2.5 \\ \text { Fe-COTI-2 } & 9.32 \pm 3.29 & 7.13 \pm 2.91 & 0.7^{\text {n.s. }} & 3.62 \pm 0.80 & 0.3^{* *} \\ \text { Cu-COTI-2 } & 0.04 \pm 0.01 & 0.48 \pm 0.05 & 12.0^{* *} & 0.04 \pm 0.01 & 1.1^{\text {n.s. }}\end{array}$

${ }^{a} \mathrm{IC}_{50}$ values were calculated from concentration-response curves. Values are given as mean $\pm \mathrm{SD}$ of three independent experiments performed in triplicates. ${ }^{b}$ Differences in sensitivity calculated by dividing the $\mathrm{IC}_{50}$ values of the resistant subline by those of the parental line. $* * * p \leq 0.001, * * p$ $\leq 0.01, *_{p} \leq 0.05$; n.s. (not significantly different), calculated by one-sample $t$-test. ${ }^{c}$ Taken from ref.

chain structure instead of the bridging chlorido ligands for COTI-2 (even though the distances and angles are very similar). ${ }^{28}$ Notably, such dimeric structures with a metal-toligand ratio of 1:1 are usually only present in the solid state and dissociate in aqueous solution at room temperature into the respective monomers.

Activity against Chemosensitive and Thiosemicarbazone-Resistant Cancer Cells. We have recently reported on an SW480 subline with acquired resistance to Triapine (SW480/Tria, Figure 2 left), which was characterized by upregulation of $\mathrm{ABCB} 1^{16}$ and the loss of phosphodiesterase $4 \mathrm{D} .{ }^{33}$ To investigate the resistance profile against COTI- 2 and test the cross-resistance against its metal complexes, COTI$\mathrm{NH}_{2}$ and Triapine, in the course of this study, a new cell line with acquired resistance to COTI-2 was established. Notably, there is already one report in literature that COTI-2 did not induce resistance in the human lung cancer cell lines DMS153, SHP-77, and A549. ${ }^{34}$ However, in this study, the lung cancer cells were exposed only to a short-term treatment (four rounds in 4 days) of COTI-2. Consequently, we chose a different selection approach, and the resistant cells, termed SW480/Coti, were generated by continuous exposure of chemonaive SW480 cells to increasing concentrations of COTI-2 over a period of approximately one year. At that time, SW480/Coti cells displayed a 19-fold resistance compared to parental SW480 cells (Figure 2 right, Table 1 ).

Subsequently, the impact of the $N^{4}$-terminal modification of COTI- 2 and metal complexation on the anticancer activity and resistance profile was assessed by comparing $\mathrm{IC}_{50}$ values in the parental SW480 cells to the ones in SW480/Tria and SW480/ Coti cells (Table 1 and Figure S2).

In the sensitive SW480 cells, the anticancer activity of COTI-2 was in the upper nanomolar range with an $\mathrm{IC}_{50}$ value of $0.56 \mu \mathrm{M}$, slightly lower than that of Triapine with an $\mathrm{IC}_{50}$ of $0.82 \mu \mathrm{M}$. In contrast, COTI- $\mathrm{NH}_{2}$ displayed distinctly weaker activity (14-fold less active than COTI-2). That terminally unsubstituted derivatives like Triapine and COTI- $\mathrm{NH}_{2}$ show much lower cytotoxic activity, it is in line with previous publications on other thiosemicarbazones ${ }^{8,9,35,36}$ and demonstrates the strong impact of $N^{4}$-terminal modification on the anticancer activity of thiosemicarbazones. Noteworthy, also, the thiosemicarbazone resistance profile was strongly affected by the $N^{4}$-terminal alterations. In detail, while SW480/Coti cells were 18.9-fold resistant against COTI-2 compared to the parental cells, Triapine was not affected by the acquired COTI2 resistance, and SW480/Coti cells displayed even collateral sensitivity to COTI-NH $\mathrm{N}_{2}$. On the opposite, SW480/Tria cells were cross-resistant against COTI- $\mathrm{NH}_{2}$ but not COTI-2. This indicates that a terminal $\mathrm{NH}_{2}$ moiety is important for resistance of SW480/Tria but not of SW480/Coti cells.

In case of the metal complexes of COTI-2, complexation of iron significantly reduced its activity by 19 -fold in parental SW480 cells. This is in agreement to a previous report, ${ }^{8}$ which showed a 3 -fold decreased activity of the iron(III) complex of Triapine (in $41 \mathrm{M}$ and SK-BR-3 cells) compared to the metalfree ligand. The lower activity upon iron complexation could be explained by a decreased uptake of the complexes (maybe due to their positive charges, which impairs cell membrane crossing). With regard to the resistance profile, SW480/Coti cells were not cross-resistant to Fe-COTI-2, while SW480/Tria cells even showed collateral sensitivity. This could indicate that the remaining activity of COTI-2 against SW480/Coti is based on an intracellularly formed iron complex, which is not recognized by the mechanisms underlying the drug resistance of the COTI-2-resistant subclone (vide infra). In general, the collateral sensitivity of the ABCB1-overexpressing SW480/Tria cells to Fe-COTI-2 is interesting; as in a recent report of Szakács et al. $^{37}$ the iron complex of the 8-hydroxyquinolinebased iron chelator and ribonucleotide reductase inhibitor NSC297366 turned out to be an ABCB1 substrate, which 
A

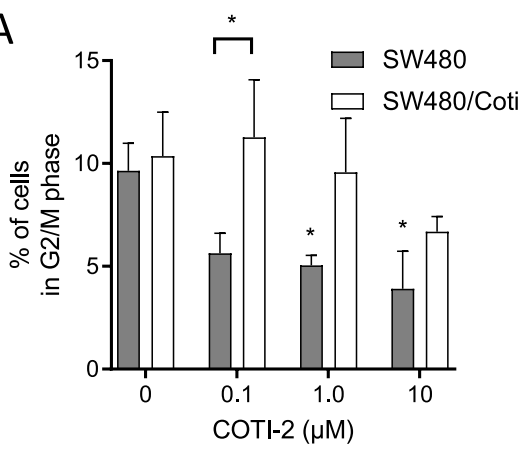

C

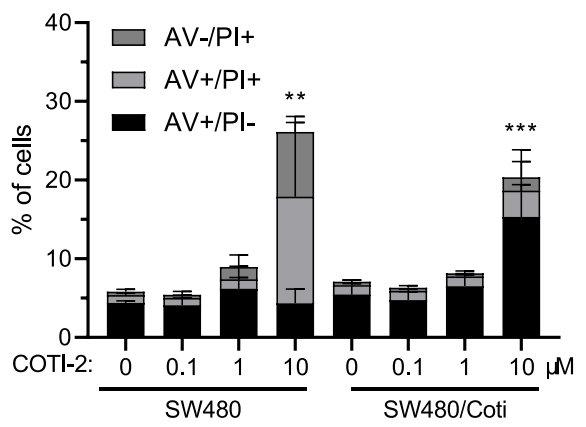

$\mathrm{E}$

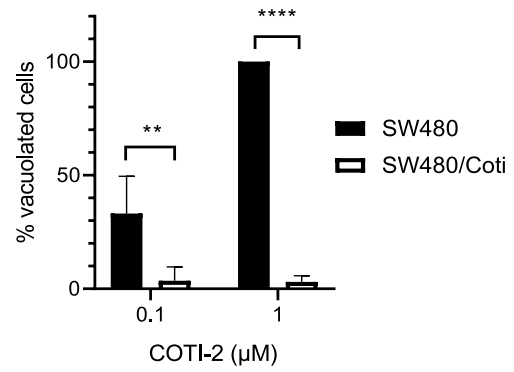

B

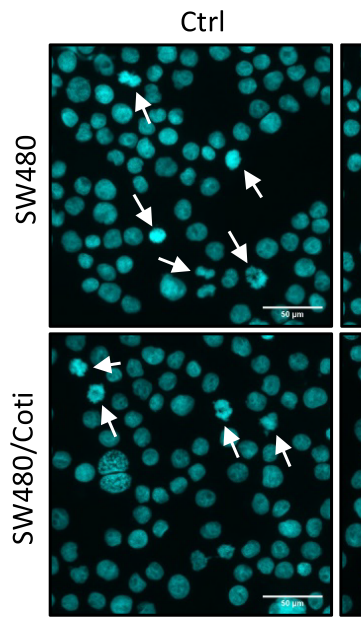

$1 \mu \mathrm{M}$ COTI-2

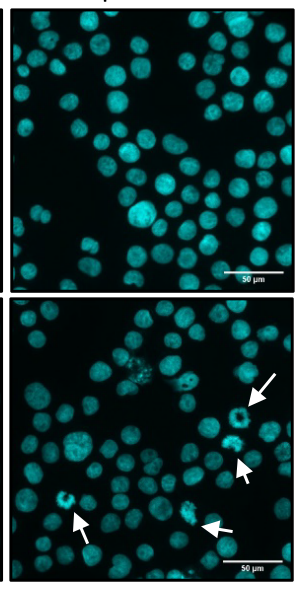

D

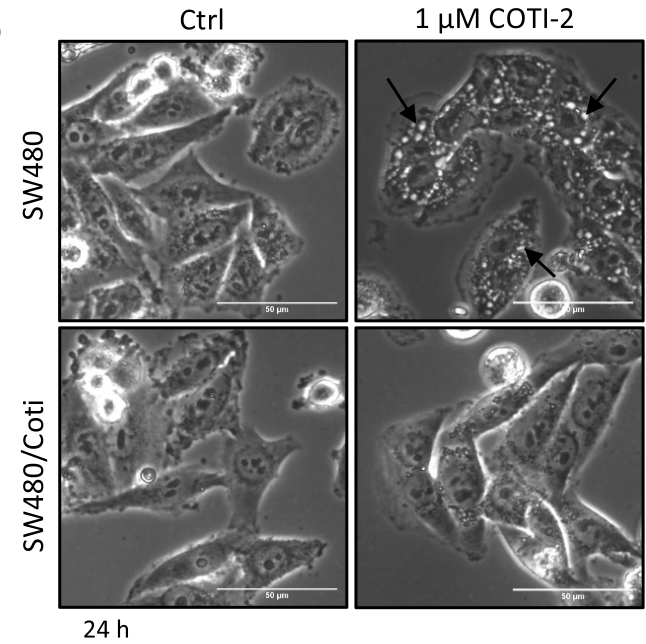

Figure 3. Cell cycle arrest and cell death induction by COTI- 2 in SW480 and SW480/Coti cells after 24 h treatment. (A) The percentage of cells in G2/M phase was analyzed by staining ethanol-fixed cells with propidium iodide (PI) followed by flow cytometry. Mean \pm SD was derived from three independent experiments. (B) Nucleic morphology was analyzed by DAPI staining of methanol/acetone (1:1)-fixed cells. Mitotic cells are indicated with an arrow (scale bar: $50 \mu \mathrm{m}$ ). (C) Cell death induction was analyzed by AV and PI stain followed by flow cytometry. Mean \pm SD was derived from three independent experiments. (D) Representative microscopy images of paraptotic vesicle formation (arrow) in SW480 and SW480/Coti cells after $24 \mathrm{~h}$ treatment with $1 \mu \mathrm{M}$ COTI-2 (scale bar: $50 \mu \mathrm{m}$ ). (E) Percentage of vacuolated cells (counted in Image J). Mean \pm SD was derived from three independent experiments. Significance between cell lines (asterix between bars) was calculated in (A) and (E) by twoway ANOVA and the Sidak's multiple comparison test. Significant difference to the control group (indicated by the asterisk above bar) was calculated in (A) and (C) by one-way ANOVA and the Dunnett's multiple comparison test $(p<0.05 *, p<0.01 * *, p<0.001 * * *, p<0.0001$ $* * * *)$.

resulted in the hypothesis that the collateral sensitivity is based on ABCB1-mediated iron efflux. This indicates that, although these two compound classes share certain aspects of their modes of action, the mechanisms underlying the collateral sensitivity of $\mathrm{ABCB} 1$-overexpressing cells against certain iron chelators and thiosemicarbazones might be even more complex.

In contrast to iron, complexation with copper led to a 14fold higher anticancer activity compared to the metal-free COTI-2 in the chemosensitive SW480 cells. In general, this enhanced sensitivity is in good agreement with previous data from others and our group. ${ }^{6,38}$ In these studies (although no significant difference was observed in the $\mathrm{IC}_{50}$ values after $72 \mathrm{~h}$ ), shorter incubation times ( 3 or $24 \mathrm{~h}$ ) or very toxic drug concentrations ( $\mathrm{IC}_{90}$ values) revealed a marked increase in activity of the copper complexes of nanomolar-active thiosemicarbazones such as $\mathrm{Me}_{2} \mathrm{NNMe}_{2}, \mathrm{DpC}$, Dp44mT, PTSC. 6,38 This supports the current hypothesis that the copper complex plays an important role in the mode of action of these nanomolar-active thiosemicarbazones. ${ }^{4,10,39,40}$ Regarding the resistance profile, similar to the metal-free ligand, $\mathrm{Cu}$ COTI-2 was 12-fold less active in SW480/Coti cells compared to parental cells, but it was not affected by the resistance of SW480/Tria cells. This indicates that, in contrast to the iron complex, $\mathrm{Cu}-\mathrm{COTI}-2$ is recognized by similar resistance mechanisms as the metal-free ligand. Taken together, the cell viability investigations revealed that the acquired resistance against COTI-2 is distinctly different from that of Triapine and metal complexation can result in strong changes of the resistance profile.

To gain more insights into the mode of resistance of the SW480/Coti cells, the impact of COTI-2 on cell cycle distribution (Figure 3A,B and Figure S3) and cell death levels of SW480 versus SW480/Coti was investigated. In agreement with the comparable growth curves of both parental and resistant cells, the cell cycle distribution without treatment was 

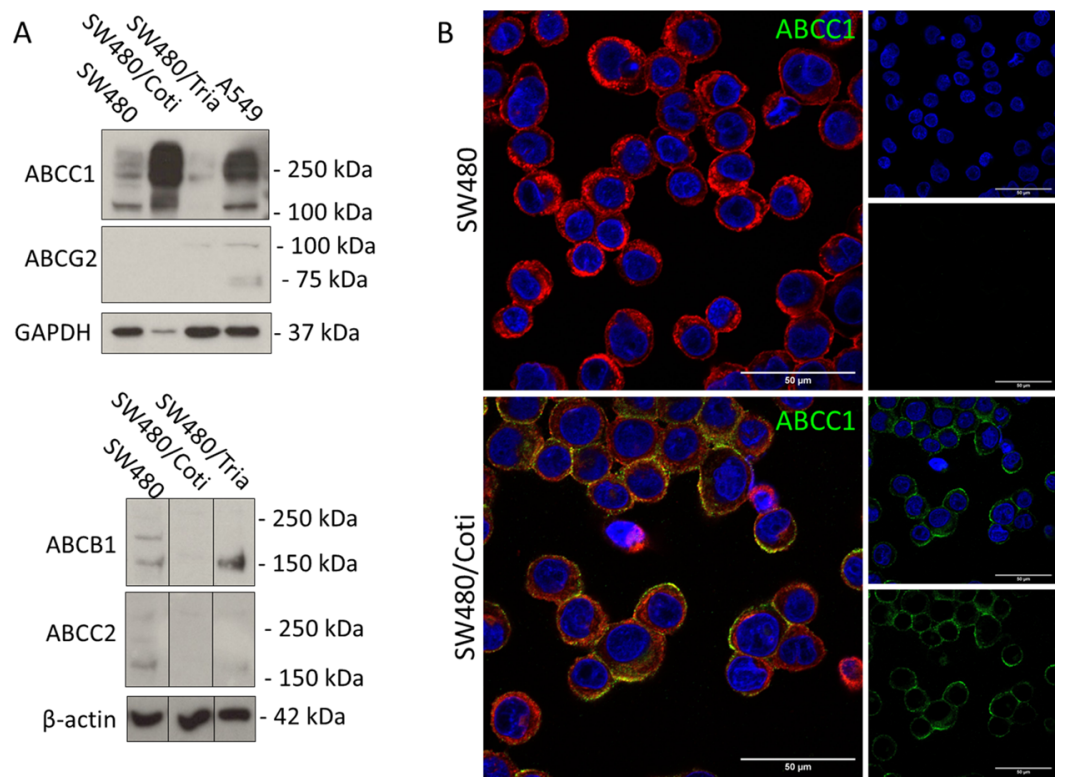

Figure 4. $A B C$ transporter expression of the investigated SW480 cell clones. (A) Protein expression of ABC transporters was investigated in membrane-enriched fractions of the indicated cell lines by Western blotting. GADPH and $\beta$-actin were used as loading controls and A549 as positive control for $\mathrm{ABCC} 1$ and $\mathrm{ABCG} 2$ expression. Borders between cell lines indicate the rearrangement of original lanes of the same blot. (B) Immunofluorescence staining of ABCC1 (green) in SW480 and SW480/Coti cells. Cells were transferred to microscopy slides by cytospin and fixed with $4 \%$ PFA. DAPI (blue) and rhodamine-conjugated wheat-germ agglutinin (red) were used as counterstains for nuclei and membranes, respectively. (Scale bar: $50 \mu \mathrm{m}$ ).
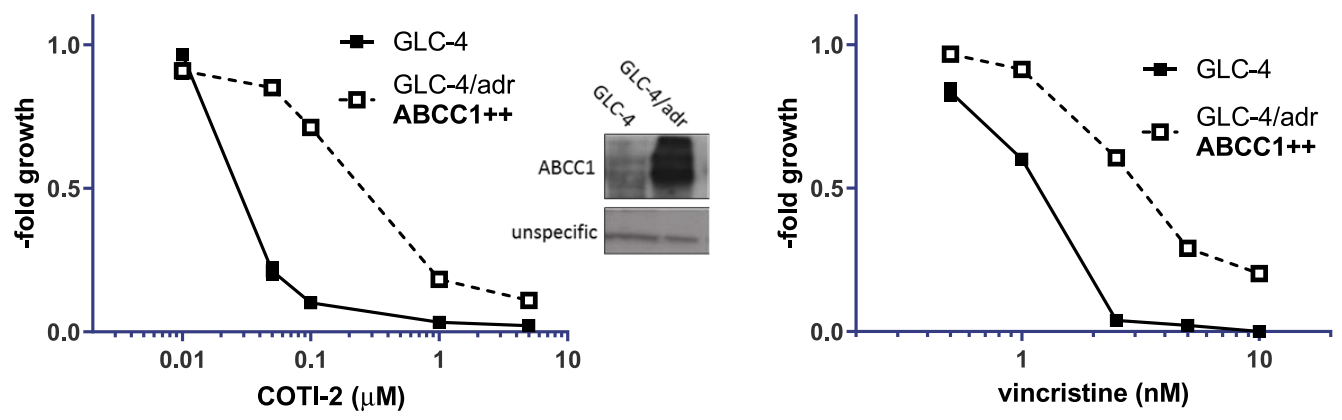

Figure 5. Influence of ABCC1 expression on the activity of COTI-2. Anticancer activity of COTI-2 was tested in GLC-4 and GLC-4/adr lung cancer cells by the MTT assay after $72 \mathrm{~h}$ drug incubation. Vincristine, a known ABCC1 substrate, was used as a reference drug. Values given are means \pm SD of three experiments performed in triplicates. The insert shows a Western blot of membrane-enriched protein fractions confirming the overexpression of ABCC1 in GLC-4/adr compared to parental GLC-4 cells.

rather similar between SW480 and SW480/Coti cells (Figure $\mathrm{S} 3 \mathrm{~A})$. Drug treatment led to a significant reduction of $\mathrm{G} 2 / \mathrm{M}$ phase cells in comparison to untreated controls in SW480 but not in the resistant subline (Figure 3A). In SW480/Coti cells, only at the highest COTI- 2 concentration of $10 \mu \mathrm{M}$, changes in cell cycle distribution (shift of cells from G0/G1 into Sphase) were observed (Figure 3A and Figure S3B). Preliminary microscopy analysis indicated that the observed reduction in the $\mathrm{G} 2 / \mathrm{M}$ population is associated with a loss of the mitotic cell faction (Figure 3B).

With regard to cell death induction, annexin $\mathrm{V}(\mathrm{AV}) /$ propidium iodide (PI) stains (Figure 3C) showed that, after $24 \mathrm{~h}$ treatment, most of the parental cells were already in a late-phase cell-death $(\mathrm{AV}+/ \mathrm{PI}+)$ state, while SW480/Coti cells were still in the early phase of cell death $(\mathrm{AV}+/ \mathrm{PI}-)$. In addition, also the induction of paraptotic cell death, measured by the increase of cytoplasmic vesicles, was less pronounced in the resistant cell model (Figure 3D,E). Overall, these observations point out that SW480/Coti cells are characterized by a less pronounced and delayed onset of COTI-2 activity, suggesting a resistance mechanism affecting the intracellular drug levels.

SW480/Coti Cells Express High Levels of the $A B C$ Transporter Efflux Pump ABCC1. From previous studies, we know that resistance development against anticancer thiosemicarbazones is often associated with upregulation of ABC transporter efflux pumps. ${ }^{16,17,33}$ Consequently, SW480/ Coti and SW480/Tria cells were assessed on the protein level for upregulation of the most frequently resistance-associated $\mathrm{ABC}$ transporters (ABCB1, $\mathrm{ABCC} 1, \mathrm{ABCC} 2$, and $\mathrm{ABCG} 2$ ) (Figure 4). In line with literature, ${ }^{16}$ SW480/Tria cells showed an upregulation of $\mathrm{ABCB} 1$, while the expression levels of $A B C C 1$ and $A B C C 2$ were decreased compared to parental SW480 cells. In contrast, SW480/Coti cells upregulated $\mathrm{ABCC} 1$ in concert with a downregulation of $\mathrm{ABCB} 1$ and ABCC2 (Figure 4A). In both resistant and the parental SW480 cells, protein levels of ABCG2 were too low for detection. The expression and membrane localization of ABCC1 in SW480/ 
Coti were also confirmed by immunofluorescent staining (Figure 4B). Moreover, previous studies on parental SW480 cells showed that Triapine treatment stimulated ABCB1 expression already after short-term incubation $(24 \mathrm{~h}),{ }^{16}$ so similar experiments were also performed with SW480/Coti cells. In contrast to Triapine, short-term incubation with COTI-2 was not sufficient for the stimulation of $\mathrm{ABCC} 1$ expression (Figure $\mathrm{S} 4$ ), indicating that the $\mathrm{ABCC} 1$ expression is not due to an unspecific stress response. This is also in line with the report on the human lung cancer cell lines DMS-153, SHP-77, and A549 in which short-term treatment of four rounds during 4 days was not able to induce COTI-2 resistance. $^{34}$

Identification of COTI-2 and Cu-COTI-2 as ABCC1 Substrates. Our previous investigations ${ }^{16}$ revealed that Triapine is only a weak ABCB1 substrate, and thus, upregulation of the transporter was not the major factor underlying the resistance in SW480/Tria cells. Therefore, we investigated if COTI- 2 is indeed an ABCC1 substrate. To do so, as a first step, we assessed the activity of all compounds (COTI-2, its metal complexes, COTI- $\mathrm{NH}_{2}$ and Triapine) in a known ABCC1-overexpressing cell model (GLC-4/adr) and compared the $\mathrm{IC}_{50}$ values to the ones of parental GLC-4 cells (Figure 5 left, Table 2, and Figure S5). As confirmation of the functional $\mathrm{ABCC} 1$ in this cell model, the known $\mathrm{ABCC} 1$ substrate vincristine was used (Figure 5 right).

Table 2. Differences in Viability of GLC-4 and ABCC1Overexpressing GLC-4/adr Cells Treated with COTI-2, COTI-NH ${ }_{2}$, Fe-COTI-2, Cu-COTI-2, and Triapine for $72 \mathrm{~h}$

$\begin{array}{lcccc}\text { compound } & \begin{array}{c}\mathrm{GLC}-4 \\ \left(\mathrm{IC}_{50}, \mu \mathrm{M}\right)^{a}\end{array} & \begin{array}{c}\mathrm{GLC}-4 / \mathrm{adr} \\ \left(\mathrm{IC}_{50}, \mu \mathrm{M}\right)^{a}\end{array} & \begin{array}{c}\text { relative } \\ \text { resistance }^{b}\end{array} & \begin{array}{c}\mathrm{ABCC1}^{c} \\ \text { substrate }^{c}\end{array} \\ \text { COTI-2 } & 0.03 \pm 0.01 & 0.48 \pm 0.15 & 17.3^{*} & \text { YES } \\ \text { Triapine } & 0.65 \pm 0.09 & 0.57 \pm 0.05 & 0.9^{\text {n.s. }} & \text { NO } \\ \text { COTI-NH } & 3.64 \pm 0.39 & 3.65 \pm 0.41 & 1.0^{\text {n.s. }} & \text { NO } \\ \text { Fe-COTI-2 } & 0.79 \pm 0.07 & 0.80 \pm 0.11 & 1.0^{\text {n.s. }} & \text { NO } \\ \text { Cu-COTI-2 } & 0.02 \pm 0.01 & 0.06 \pm 0.02 & 3.2^{*} & \text { YES }\end{array}$

${ }^{a} \mathrm{IC}_{50}$ values were calculated from concentration-response curves measured by the MTT assay. Values are given as mean \pm SD of two or three independent experiments, in triplicates. ${ }^{b}$ Relative resistance was calculated by dividing the $\mathrm{IC}_{50}$ values of the resistant GLC-4/adr by those of the parental GLC- 4 cells. ${ }^{*} p \leq 0.05$; n.s., not significantly different; calculated by one-sample $t$-test. ${ }^{c}$ Proposed substrate assignment based on data of GLC-4 and SW480 models.

Indeed, the $\mathrm{ABCC} 1$-overexpressing GLC-4/adr cells were 17.3-fold resistant to COTI-2 in comparison to the parental GLC-4 cells. In addition, also, Cu-COTI-2 showed (in agreement with the resistance of SW480/Coti cells) reduced activity in GLC-4/adr cells, suggesting them as potential ABCC1 substrates (Table 2). In contrast, COTI- $\mathrm{NH}_{2}, \mathrm{Fe}-$ COTI-2, and Triapine were not affected by the multidrug resistance of GLC-4/adr cells.

To confirm that the resistance of SW480/Coti cells is based on enhanced (ABCC1-mediated) drug efflux, it was tested whether the respective resistance against COTI- 2 could be reversed by combination with the known $\mathrm{ABC}$ transporter modulators verapamil and cyclosporine A (CSA). The modulators alone (at the used concentrations) did not impact on the growth of neither SW480 nor SW480/Coti cells to a relevant extent (less than $15 \%$ reduction in cell number, data not shown). Indeed, the addition of verapamil or CSA was able to efficiently reverse the resistance of SW480/Coti cells against COTI-2 and the known ABCC1 substrate vincristine (Figure 6). In contrast, COTI-NH$H_{2}$ and Triapine were not affected in their activity by the addition of the modulator drugs, further supporting the hypothesis that they are not transported by ABCC1 expressed by SW480/Coti cells.

Role of GSH in the Resistance of SW480/Coti Cells against COTI-2, COTI- $\mathrm{NH}_{2}$, and Triapine. ABCC1 is known for its high phase II conjugate substrate specificity. Thus, the protein has been shown to efflux various neutral and anionic hydrophobic compounds and products of phase II drug metabolism, including many GSH and glucuronide conjugates. $^{18}$ Moreover, contrary to other transport proteins involved in cancer-related multidrug resistance (MDR), the activity of ABCC1 is related to the GSH content of cells. ${ }^{19}$ To investigate the role of GSH in the resistance of SW480/Coti cells, buthionine sulphoximine (BSO), an inhibitor of the de novo synthesis of GSH, was utilized. ${ }^{41}$ SW480 and SW480/ Coti cells were pretreated with BSO for $18 \mathrm{~h}$ before the addition of COTI-2, COTI-NH $\mathrm{NH}_{2}$, or Triapine for $72 \mathrm{~h}$ after which cell viability was measured by MTT (Figure 7). Indeed, BSO resensitized SW480/Coti cells against the anticancer activity of COTI-2. Moreover, these experiments revealed that SW480/Coti cells were distinctly more sensitive to BSO treatment than the parental SW480 cells (up to $40 \%$ reduction in the cell number in SW480/Coti cells compared to $20 \%$ in SW480 cells at $25 \mu \mathrm{M}$ BSO). Interestingly, BSO treatment had a strong sensitizing effect on cells treated with $\mathrm{COTI}-\mathrm{NH}_{2}$, which was similar in SW480 and SW480/Coti cells. This effect seems to be independent from the $\mathrm{ABCC} 1$ expression of the SW480/Coti cells and indicates to a specific protective mechanism of GSH against this new derivative but not COTI-2. Taken together, these experimental findings show that GSH synthesis is crucial for SW480/Coti resistance and transportation of COTI-2 by ABCC1.

Reaction of the Cu-COTI Complexes with GSH. While these results demonstrate that GSH plays a role in drug export of COTI-2, it is not clear how a GSH adduct can be formed, or more general, how can a thiosemicarbazone be pumped by $\mathrm{ABCC} 1$ in a GSH-dependent manner? We recently investigated a possible direct conjugation of GSH to a nanomolaractive thiosemicarbazone (2-acetylpyridine 4,4-dimethylthiosemicarbazone, KP1550) using the enzyme gluathione-S-transferase. ${ }^{17}$ However, no adduct formation could be observed in these studies, prompting us to the hypothesis that the thiosemicarbazone could be effluxed in co-transport with unconjugated GSH. A different explanation would be the generation of a GSH adduct via the intracellularly formed copper-thiosemicarbazone complex and its transport by ABCC1. Thus, we investigated the reaction of the copper(II) complexes of COTI-2, COTI- $\mathrm{NH}_{2}$, and Triapine with GSH spectrophotometrically at $\mathrm{pH} 7.4$ in aqueous solution under anaerobic conditions. The complexes besides $\mathrm{Cu}-\mathrm{COTI}-2$ were prepared in situ by mixing the metal ion and ligand at the 1:1 ratio. Notably, copper(II) complexes of $\alpha$-N-pyridyl thiosemicarbazones bearing an $\mathrm{N}, \mathrm{N}, \mathrm{S}^{-}$coordination mode are generally highly stable at physiological $\mathrm{pH}$ even at fairly low concentrations. ${ }^{4,6}$

Compared to the metal-free ligands, in all copper complexes, a larger increase in absorbance was observed in the wavelength range $\sim 360-460 \mathrm{~nm}$ due to the $S \rightarrow \mathrm{Cu}$ charge transfer band (Figure 8; free ligands in dashed lines, copper complexes without GSH in red). Immediately after the addition of GSH, 

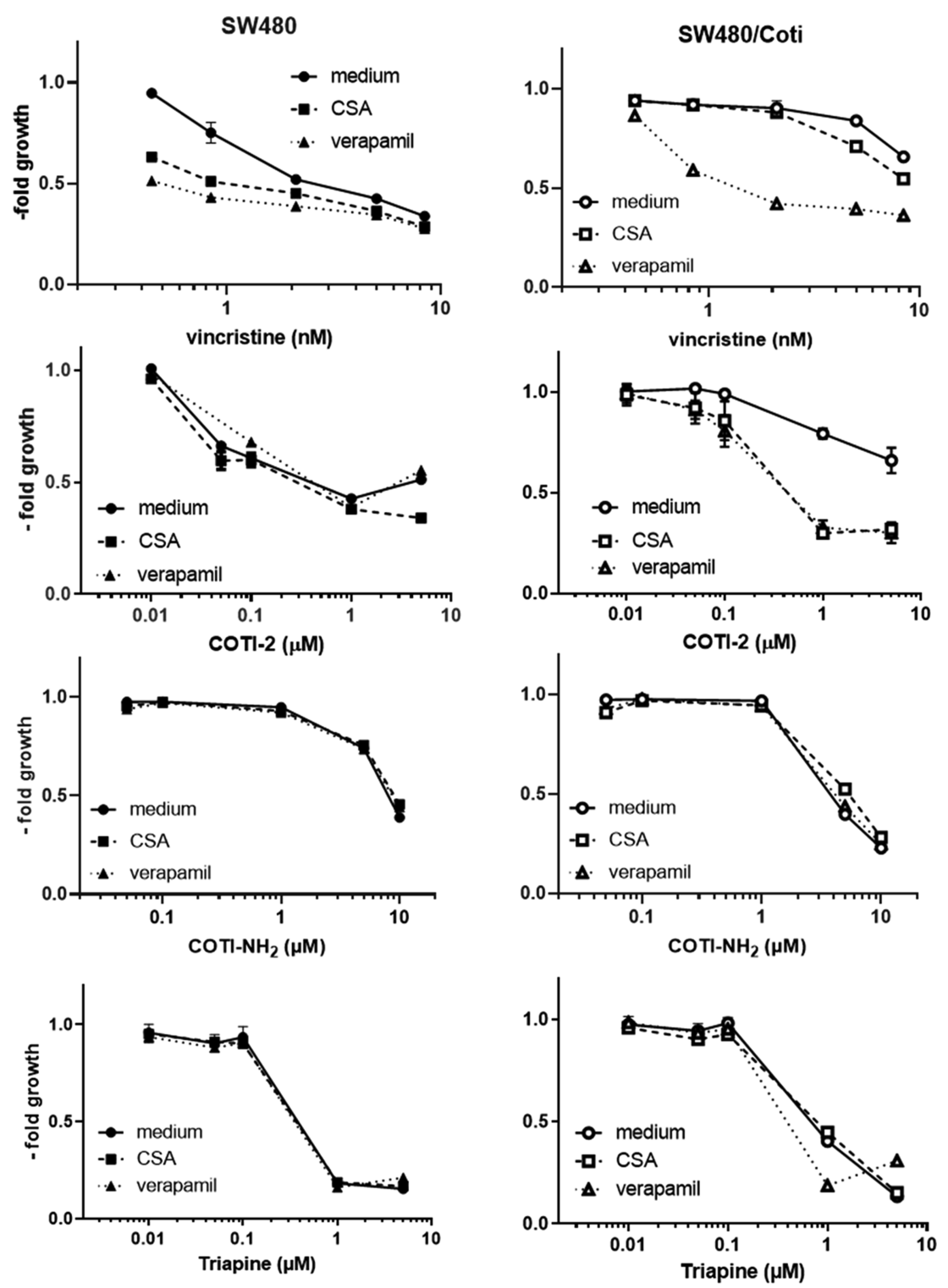

Figure 6. Impact of $\mathrm{ABC}$ transporter modulators $(1 \mu \mathrm{M} \mathrm{CSA}$ and $10 \mu \mathrm{M}$ verapamil) on the anticancer activities of vincristine, COTI-2, COTI$\mathrm{NH}_{2}$, and Triapine in the SW480/Coti cells in comparison to the parental cells. Vincristine was used as a positive control of an ABCC1 substrate. Viability was measured by the MTT assay after $72 \mathrm{~h}$ of combined drug treatment. Mean \pm SD was derived from triplicates of one representative experiment out of three. Values are given normalized to their respective controls. Thus, modulator controls were set to 1.

for all complexes, a small shift of the $\lambda_{\max }$ value around $380-$ $400 \mathrm{~nm}$ could be observed (Figure 8, bold black lines). This can be explained by the formation of a mixed-ligand complex with GSH via the coordination of the thiolate at the fourth coordination site of the copper(II), as also reported for similar complexes. ${ }^{6,42,43}$ For Cu-COTI-2, this was also proven by mass spectrometry measurements, clearly indicating the respective GSH-Cu-COTI-2 complex at $m / z=735$ (Figure S6). This GSH-adduct formation was similar for all copper(II) complexes, but over time, a very different behavior was observed. In case of $\mathrm{Cu}-\mathrm{COTI}-\mathrm{NH}_{2}$, the absorbance of the $\mathrm{S}$ $\rightarrow \mathrm{Cu}$ charge transfer band decreased, while it was increased at the $\lambda_{\max }$ of the free ligand (Figure 8A). This can be explained by a reduction of the metal center and release of the thiosemicarbazone from copper(I) with the formation of a copper(I)-GSH complex (due to the high excess of GSH, we cropped the spectra at wavelengths $<310 \mathrm{~nm}$, where GSH and its $\mathrm{Cu}(\mathrm{I})$ complex absorb). However, the redox reaction was far from being complete after the $6 \mathrm{~h}$ measurement time. In contrast, in case of $\mathrm{Cu}$-COTI-2, after the initial changes due to the GSH addition, the spectra were almost unchanged within $6 \mathrm{~h}$ (Figure 8B). For the reference complex $\mathrm{Cu}$-Triapine (Figure $8 \mathrm{C}$ ), the reduction was even distinctly faster than for $\mathrm{Cu}-\mathrm{COTI}-\mathrm{NH}_{2}$ with a nearly complete reduction and release of free Triapine already after 20 min. $^{6}$ For comparison, the changes of the absorbance values at the $\lambda_{\max }$ of the $S \rightarrow \mathrm{Cu}$ charge transfer band were plotted for all investigated complexes as a function of time (Figure $8 \mathrm{D}$ ). This clearly shows that the redox reaction is very fast in case of $\mathrm{Cu}$ Triapine and moderate for $\mathrm{Cu}-\mathrm{COTI}-\mathrm{NH}_{2}$, while it does not take place at a measurable level with $\mathrm{Cu}-\mathrm{COTI}-2$. This is in line with very recent GSH reduction data of copper(II) complexes of other thiosemicarbazones, where terminally unsubstituted thiosemicarbazones also showed much faster reduction kinetics than their respective disubstituted derivatives. ${ }^{6}$ In addition, we investigated the same reaction of the 

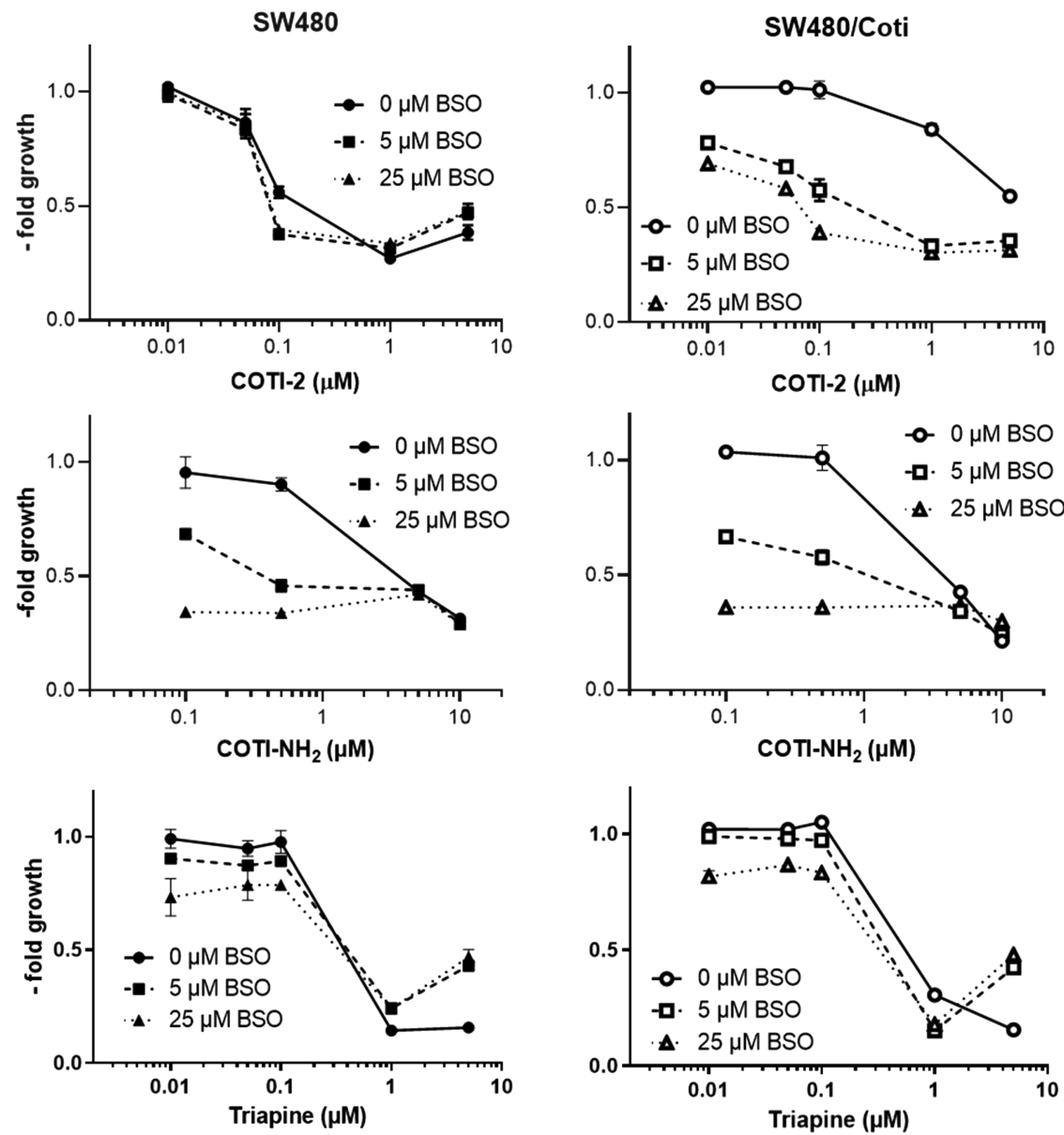

Figure 7. Impact of GSH synthesis inhibition by BSO on the anticancer activity of COTI-2, COTI-NH 2 , and Triapine in SW480 and SW480/Coti cells. BSO was added $18 \mathrm{~h}$ before drug treatment, and viability was measured by MTT after $72 \mathrm{~h}$ of drug treatment. Mean \pm SD was derived from triplicates of one representative experiment out of three.

Cu-COTI-2 complex with GSH in cell culture medium (RPMI-1640) as a solvent instead of HEPES buffer (Figure S7). Again, the addition of GSH led to a shift in $\lambda_{\max }$ according to the formation of the mixed-ligand complex with GSH. Over time, just small changes could be observed indicating very high redox stability also in the presence of high excess amino acids (up to $2 \mathrm{mM})$ and alkaline earth metals ( $\sim 400 \mu \mathrm{M} \mathrm{Mg}$ (II) and $\mathrm{Ca}(\mathrm{II}))$.

When we compare the copper complex reduction kinetics in the presence of GSH with the resistance profiles, we clearly see that the GSH-Cu(II)-TSC complexes of COTI- $\mathrm{NH}_{2}$ and Triapine, which are easily reduced together with dissociation of the thiosemicarbazone ligand, are no $\mathrm{ABCC} 1$ substrates. In contrast, the very stable GSH-Cu(II)-TSC complexes of COTI- 2 and preformed $\mathrm{Cu}-\mathrm{COTI}-2$ are nonreducible and are affected by $\mathrm{ABCC} 1$ transportation. This is in line with the hypothesis that the GSH-Cu(II)-TSC adduct is the species transported by ABCC1. The observation that Fe-COTI-2 did not react with GSH (data not shown) explains why the COTIresistant cells were not resistant against this complex and it is no $\mathrm{ABCC} 1$ substrate.

\section{CONCLUSIONS}

Here, in the presented study, the first COTI-2 metal complexes were synthesized using the physiologically relevant metal ions, iron(III) and copper(II). Subsequently, these new compounds were biologically investigated in comparison to several metal- free thiosemicarbazone ligands to determine the effect of metal complex formation on the anticancer activity and drug resistance profile of COTI-2. To this end, the anticancer activity was tested in chemosensitive and thiosemicarbazoneresistant SW480 cells, including the newly generated COTI-2resistant SW480/Coti model. Distinct differences in the resistance profile of the individual thiosemicarbazones and metal complexes were observed. The two terminally nonsubstituted ligands COTI- $\mathrm{NH}_{2}$ and Triapine as well as the iron(III) complex of COTI-2 were not affected by the ABCC1based resistance of the SW480/Coti cells. In turn, COTI- $\mathrm{NH}_{2}$ was a substrate for the resistance of the Triapine-selected SW480/Tria cells (which are characterized by ABCB1 overexpression and the loss of phosphodiesterase 4D). ${ }^{16,33}$ In contrast, the copper complex of COTI- 2 resembled COTI- 2 in its resistance profile being an $\mathrm{ABCC} 1$ substrate.

Noteworthy, $\mathrm{ABCC} 1$ is an efflux pump known for its substrate specificity for GSH and other conjugates of the phase II metabolism. ${ }^{18}$ In addition, it has been repeatedly reported that copper complex formation plays an important role in the anticancer activity of nanomolar-active thiosemicarbazones such as DpC or Dp44mT. ${ }^{4,39,40,44}$ This prompted us to the hypothesis that the GSH adduct formed with the copper(II) complexes of the thiosemicarbazones ${ }^{43}$ is the species exported by $\mathrm{ABCC} 1$. Indeed, the copper complex of COTI-2 forms a stable and nonreducible adduct with GSH. There is increasing evidence that the specific copper chemistry of certain 
A

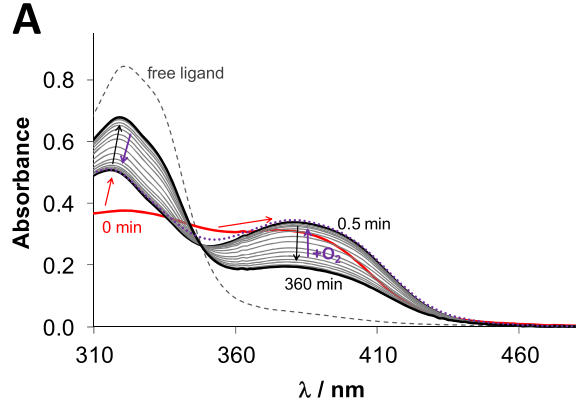

C

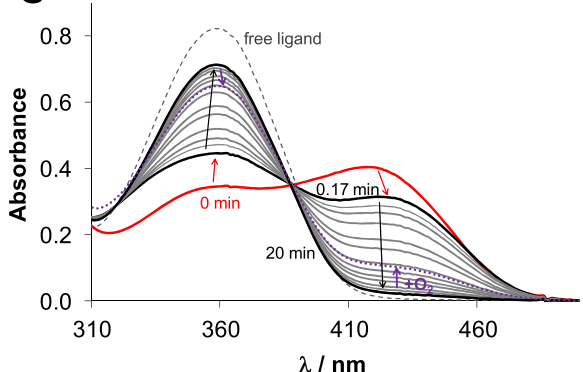

B
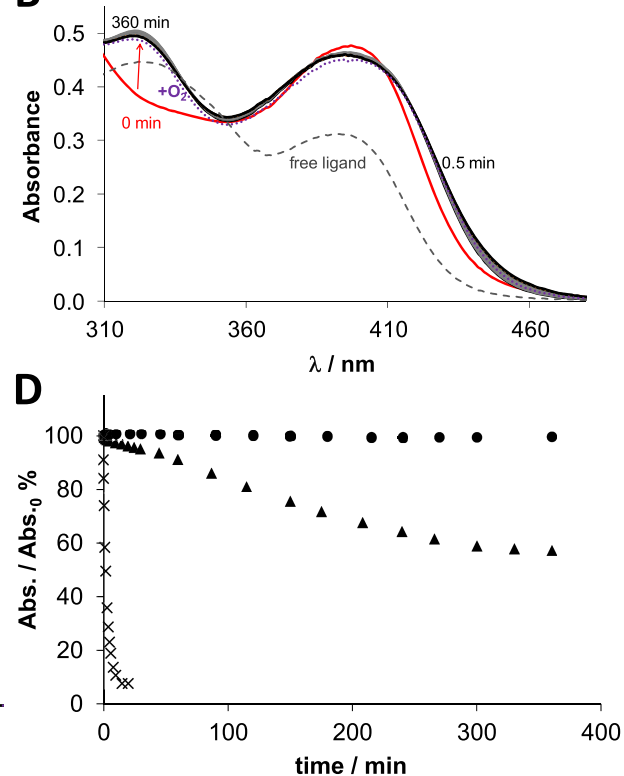

Figure 8. Time-dependent changes of the UV-vis spectra of the (A) Cu-COTI- $\mathrm{NH}_{2}$, (B) Cu-COTI-2, and (C) Cu-Triapine complex (30 $\left.\mu \mathrm{M}\right)$ in the presence of 300 equiv of GSH at pH 7.4 in aqueous solution under anaerobic conditions. $\left(T=25^{\circ} \mathrm{C} ; \mathrm{pH}=7.40\right.$ (50 mM HEPES)). Dashed lines represents the metal-free ligand and red lines the $\mathrm{Cu}$-TSC complex without GSH. Red arrows indicate the change after the addition of GSH, black arrows after incubation with GSH for up to $360 \mathrm{~min}$ and violet arrows after oxygen exposure. (D) Time-dependent absorbance changes at the $\lambda_{\max }$ of the $\mathrm{S} \rightarrow \mathrm{Cu}$ charge transfer band for the $\mathrm{Cu}-\mathrm{COTI}-2$ (circle solid), Cu-COTI-NH${ }_{2}$ (triangle up solid), and Cu-Triapine complex (times) $(30 \mu \mathrm{M})$ in the presence of 300 equiv of GSH at $\mathrm{pH} 7.4$ in aqueous solution under anaerobic conditions $\left(T=25^{\circ} \mathrm{C} ; \mathrm{pH}=7.40(50 \mathrm{mM} \mathrm{HEPES})\right)$.

thiosemicarbazones distinctly affects their biological activity (strongly enhanced cytotoxicity based on disruption of the cellular thiol homeostasis and induction of paraptotic cell death) ${ }^{6,10}$ However, this is the first report that this is also true for their drug resistance profile by offering a mechanistic explanation on how such compounds (which as metal-free ligands do not interact with GSH) are recognized and are in turn transported by $\mathrm{ABCC} 1$. It can be expected that this also impacts on the pharmacological behavior of this compound class, as $\mathrm{ABCC} 1$ is of high importance in the phase II metabolism of the healthy body. ${ }^{18}$ Moreover, the findings of this work are essential for considerations of cancer treatment strategies with thiosemicarbazones, as drug resistance is still the major obstacle for successful therapy especially at the late stage of the disease. Thus, knowledge on the resistance mechanisms allows the selection of both, an appropriate patient collective and drug candidates for combination therapy.

\section{EXPERIMENTAL SECTION}

Materials and Methods. All solvents and reagents were obtained from commercial suppliers and used without further purification. Elemental analyses were performed on a Perkin Elmer $2400 \mathrm{CHN}$ elemental analyzer at the Microanalytical Laboratory of the University of Vienna and are within $\pm 0.4 \%$, confirming $>95 \%$ purity. Electrospray ionization (ESI) mass spectra were recorded on a Bruker amaZon SL ion trap mass spectrometer in positive mode by direct infusion. High-resolution mass spectra were measured on a Bruker maXis UHR ESI time of flight mass spectrometer. Onedimensional ${ }^{1} \mathrm{H}$ NMR spectra of the precursors were recorded on a Bruker Avance III $500 \mathrm{MHz}$ spectrometer at $298 \mathrm{~K}$. One- and twodimensional ${ }^{1} \mathrm{H}$ NMR and ${ }^{13} \mathrm{C}$ NMR spectra of the final products were recorded on a Bruker Avance III $600 \mathrm{MHz}$ spectrometer at $298 \mathrm{~K}$. For ${ }^{1} \mathrm{H}$ NMR spectra, the solvent residual peak was taken as an internal reference $(\mathrm{s}=$ singlet, $\mathrm{d}=$ doublet, $\mathrm{t}=$ triplet, quint $=$ quintet, $\mathrm{dd}=$ doublet of doublets, $\mathrm{ddd}=$ doublet of doublet of doublets, $\mathrm{br}=$ broad signal, $\mathrm{m}=$ multiplet, $\mathrm{py}=$ pyridine $)$. For the NMR numbering scheme of the compounds, see Supporting Information Figures S8 and S9.

Synthesis of $N^{\prime}-(6,7-D i h y d r o q u i n o l i n-8(5 H)-y l i d e n e)-4-(p y r i d i n e-$ 2-yl)piperazine-1-carbothioamide (COTI-2). The compound was prepared in three steps (see Scheme S1) according to the patent US8034815B2. ${ }^{21}$

Synthesis of $1 \mathrm{H}-\mathrm{Imidazol}$-1-yl-(4-(pyridin-2-yl)piperazin-1-yl)methanethione (1a). Thiocarbonyldiimidazole $(0.89 \mathrm{~g}, 5.0 \mathrm{mmol}, 1$ equiv) was dissolved in dichloromethane $(30 \mathrm{~mL})$, and $\mathrm{N}$ - $(2$ pyridyl)piperazine $(762 \mu \mathrm{L}, 5.0 \mathrm{mmol}, 1$ equiv) was added. The solution was stirred overnight, and on the next day, was washed three times with water. The organic phase was dried over magnesium sulfate and evaporated. The resulting yellow oil of 1 a was dried in vacuum. Yield: $1.36 \mathrm{~g}$ (99\%). ${ }^{1} \mathrm{H}$ NMR (500.10 MHz, DMSO- $\left.d_{6}\right): \delta=2.77$ (m, $4 \mathrm{H}$, piperazine), $3.38(\mathrm{~m}, 4 \mathrm{H}$, piperazine $), 6.70(\mathrm{ddd}, J=0.6 \mathrm{~Hz}$, $\left.J=4.9 \mathrm{~Hz}, J=7.0 \mathrm{~Hz}, 1 \mathrm{H}, \mathrm{CH}_{\mathrm{py}}\right), 6.84\left(\mathrm{~d}, J=8.5 \mathrm{~Hz}, 1 \mathrm{H}, \mathrm{CH}_{\mathrm{py}}\right)$, $7.06(\mathrm{dd}, J=1.0 \mathrm{~Hz}, J=1.3 \mathrm{~Hz}, 1 \mathrm{H}$, imidazole), $7.56(\mathrm{dd}, J=1.3 \mathrm{~Hz}$, $1 \mathrm{H}$, imidazole), 7.59 (ddd, $J=1.8 \mathrm{~Hz}, J=7.0 \mathrm{~Hz}, J=8.5 \mathrm{~Hz}, 1 \mathrm{H}$, $\mathrm{CH}_{\mathrm{py}}$ ), 8.08 (dd, $J=1.0 \mathrm{~Hz}, J=1.0 \mathrm{~Hz}, 1 \mathrm{H}$, imidazole), 8.15 (ddd, $J=$ $\left.0.6 \mathrm{~Hz}, J=1.8 \mathrm{~Hz}, J=4.9 \mathrm{~Hz}, 1 \mathrm{H}, \mathrm{CH}_{\mathrm{py}}\right)$.

Synthesis of 4-(Pyridin-2-yl)-piperazine-1-carbothioamide (1b). 1a $(1.36 \mathrm{~g}, 5.0 \mathrm{mmol}, 1$ equiv) was dissolved in ethanol $(20 \mathrm{~mL})$, and hydrazine hydrate was added ( $267 \mu \mathrm{L}, 5.5 \mathrm{mmol}, 1.1$ equiv). The mixture was stirred under reflux for $2 \mathrm{~h}$, and a white solid of $\mathbf{1 b}$ was formed, which was filtered off, washed with cold ethanol, and dried in vacuum. Yield: $0.77 \mathrm{~g}(65 \%) .{ }^{1} \mathrm{H}$ NMR (500.10 MHz, DMSO- $\left.d_{6}\right): \delta$ $=3.53(\mathrm{~m}, 4 \mathrm{H}$, piperazine $), 3.85(\mathrm{~m}, 4 \mathrm{H}$, piperazine $), 4.84(\mathrm{br}, 1 \mathrm{H}$, $\mathrm{NH}), 6.66\left(\mathrm{ddd}, J=0.6 \mathrm{~Hz}, J=5.0 \mathrm{~Hz}, J=7.0 \mathrm{~Hz}, 1 \mathrm{H}, \mathrm{CH}_{\mathrm{py}}\right), 6.83$ $\left(\mathrm{d}, J=8.6 \mathrm{~Hz}, 1 \mathrm{H}, \mathrm{CH}_{\mathrm{py}}\right), 7.55(\mathrm{ddd}, J=2.0 \mathrm{~Hz}, J=7.0 \mathrm{~Hz}, J=8.6$ $\mathrm{Hz} 1 \mathrm{H}, \mathrm{CH}_{\mathrm{py}}$ ), 8.12 (ddd, $J=0.6 \mathrm{~Hz}, J=2.0 \mathrm{~Hz}, J=5.0 \mathrm{~Hz}, 1 \mathrm{H}$, $\left.\mathrm{CH}_{\mathrm{py}}\right), 9.35\left(\mathrm{~s}, 1 \mathrm{H}, \mathrm{NH}_{2}\right), 10.23\left(\mathrm{~s}, 1 \mathrm{H}, \mathrm{NH}_{2}\right)$.

Synthesis of $N^{\prime}-(6,7-D i h y d r o q u i n o l i n-8(5 H)$-ylidene)-4-(pyridine2-yl)piperazine-1-carbothioamide (COTI-2). $1 \mathrm{~b}(0.77 \mathrm{~g}, 3.26 \mathrm{mmol}$, 1 equiv) was suspended in ethanol $(25 \mathrm{~mL})$, and 6,7-dihydroquinoline-8-one was added $(0.48 \mathrm{~g}, 3.26 \mathrm{mmol}, 1$ equiv). The mixture was stirred under reflux for $20 \mathrm{~h}$, resulting in a yellow solid, which was filtered off, washed with cold ethanol and diethyl ether, and dried in vacuum. Yield: $1.01 \mathrm{~g}$ (85\%). Elemental analysis: Calcd. for $\mathrm{C}_{19} \mathrm{H}_{22} \mathrm{~N}_{6} \mathrm{~S}$ (\%): C, 62.27; H, 6.05; N, 22.90; S, 8.75. Found (\%): 
C, 61.87; H, 5.93; N, 22.58; S, 8.61. MS in ACN/MeOH $+1 \% \mathrm{H}_{2} \mathrm{O}$ (positive): $m / z$ 367.60, $[\mathrm{HL}+\mathrm{H}]^{+}$; 389.6, $[\mathrm{HL}+\mathrm{Na}]^{+} .{ }^{1} \mathrm{H}$ NMR $\left(600 \mathrm{MHz}, \mathrm{DMSO}-d_{6}\right.$; for the numbering scheme see Figure S8): Major isomer (91\%) $\delta=1.98$ (quint, ${ }^{3} J=6.1 \mathrm{~Hz}, 2 \mathrm{H}, \mathrm{CH}_{2}, \mathrm{H} 6$ ), 2.90 $\left(\mathrm{t},{ }^{3} \mathrm{~J}=6.1 \mathrm{~Hz}, 2 \mathrm{H}, \mathrm{CH}_{2}, \mathrm{H} 7\right), 3.09\left(\mathrm{t},{ }^{3} \mathrm{~J}=6.5 \mathrm{~Hz}, 2 \mathrm{H}, \mathrm{CH}_{2}, \mathrm{H} 5\right)$, $3.56\left(\mathrm{t},{ }^{3} \mathrm{~J}=5.2 \mathrm{~Hz}, 4 \mathrm{H}, \mathrm{CH}_{2}, \mathrm{H} 12,13\right), 4.10\left(\mathrm{~s}, 4 \mathrm{H}, \mathrm{CH}_{2}, \mathrm{H} 11,14\right)$, $6.66\left(\mathrm{dd},{ }^{4} J=5.2 \mathrm{~Hz},{ }^{3} J=6.9 \mathrm{~Hz}, 1 \mathrm{H}, \mathrm{CH}_{\mathrm{py}}, \mathrm{H} 16\right), 6.85\left(\mathrm{~d},{ }^{3} \mathrm{~J}=8.5\right.$ $\left.\mathrm{Hz}, 1 \mathrm{H}, \mathrm{CH}_{\mathrm{py}}, \mathrm{H} 18\right), 7.45\left(\mathrm{dd},{ }^{3} \mathrm{~J}=4.5 \mathrm{~Hz},{ }^{3} \mathrm{~J}=7.7 . \mathrm{Hz}, 1 \mathrm{H}, \mathrm{CH}_{\mathrm{py}}\right.$, $\mathrm{H} 2), 7.56\left(\mathrm{ddd},{ }^{4} J=1.9 \mathrm{~Hz},{ }^{3} \mathrm{~J}=7.1 \mathrm{~Hz},{ }^{3} \mathrm{~J}=8.3 \mathrm{~Hz}, 1 \mathrm{H}, \mathrm{CH}_{\mathrm{py}}, \mathrm{H} 17\right)$, $7.78\left(\mathrm{~d},{ }^{3} \mathrm{~J}=7.7 \mathrm{~Hz}, 1 \mathrm{H}, \mathrm{CH}_{\mathrm{py}}, \mathrm{H} 3\right), 8.13\left(\mathrm{dd},{ }^{4} \mathrm{~J}=1.3 \mathrm{~Hz},{ }^{3} \mathrm{~J}=4.8 \mathrm{~Hz}\right.$, $\left.1 \mathrm{H}, \mathrm{CH}_{\mathrm{py}}, \mathrm{H} 19\right), 8.59\left(\mathrm{dd},{ }^{4} J=1.3 \mathrm{~Hz},{ }^{3} J=4.5 \mathrm{~Hz}, 1 \mathrm{H}, \mathrm{CH}_{\mathrm{py}}, \mathrm{H1}\right)$, 14.57 (s, $1 \mathrm{H}, \mathrm{NH}, \mathrm{N} 3) .{ }^{13} \mathrm{C}$ NMR $\left(151 \mathrm{MHz}, \mathrm{DMSO}-d_{6}\right): \delta=20.2$ $\left(\mathrm{CH}_{2}, \mathrm{C} 6\right), 26.3\left(\mathrm{CH}_{2}, \mathrm{C} 5\right), 27.2\left(\mathrm{CH}_{2}, \mathrm{C} 7\right), 44.4\left(\mathrm{CH}_{2}, \mathrm{C} 12,13\right)$, $47.9\left(\mathrm{CH}_{2}, \mathrm{C} 11,14\right), 107.1\left(\mathrm{C}_{\mathrm{py}}, \mathrm{C} 18\right), 113.1\left(\mathrm{C}_{\mathrm{py}}, \mathrm{C} 16\right), 125.4\left(\mathrm{C}_{\mathrm{py}}\right.$, $\mathrm{C} 2), 136.4\left(\mathrm{C}_{\mathrm{q}}, \mathrm{C} 4\right), 137.6\left(\mathrm{C}_{\mathrm{py}}, \mathrm{C} 17\right), 137.8\left(\mathrm{C}_{\mathrm{py}}, \mathrm{C} 3\right), 148.3\left(\mathrm{C}_{\mathrm{q}}\right.$, C9), $148.2\left(\mathrm{C}_{\mathrm{py}} \mathrm{C} 1\right), 143.3(\mathrm{C}=\mathrm{N}, \mathrm{C} 8), 147.6\left(\mathrm{C}_{\mathrm{py}}, \mathrm{C} 19\right), 158.8$ $\left(\mathrm{C}_{\mathrm{q}}, \mathrm{C} 15\right), 184.0(\mathrm{C}=\mathrm{S}, \mathrm{C} 10) .{ }^{1} \mathrm{H}$ NMR (600 MHz, DMSO-d 6 ): Minor isomer $(9 \%) \delta=1.95\left(2 \mathrm{H}, \mathrm{CH}_{2}, \mathrm{H} 6^{\prime}\right), 2.73\left(2 \mathrm{H}, \mathrm{CH}_{2}, \mathrm{H} 7^{\prime}\right)$, $2.92\left(2 \mathrm{H}, \mathrm{CH}_{2}, \mathrm{H}^{\prime}\right), 3.69\left(4 \mathrm{H}, \mathrm{CH}_{2}, \mathrm{H} 12,13^{\prime}\right), 6.81(1 \mathrm{H}, \mathrm{CH}$, $\left.\mathrm{H} 18^{\prime}\right), 7.50\left(1 \mathrm{H}, \mathrm{CH}_{\mathrm{py}}, \mathrm{H} 2^{\prime}\right), 7.89\left(1 \mathrm{H}, \mathrm{CH}_{\mathrm{py}}, \mathrm{H} 3^{\prime}\right), 8.69\left(1 \mathrm{H}, \mathrm{CH}_{\mathrm{py}}\right.$ $\left.\mathrm{H}^{\prime}\right), 15.53\left(1 \mathrm{H}, \mathrm{NH}, \mathrm{N}^{\prime}\right) .{ }^{13} \mathrm{C}$ NMR (151 MHz, DMSO-d $\left.d_{6}\right): \delta=$ $22.1\left(\mathrm{CH}_{2}, \mathrm{C6}^{\prime}\right), 28.8\left(\mathrm{CH}_{2}, \mathrm{C5}^{\prime}\right), 33.4\left(\mathrm{CH}_{2}, \mathrm{C} 7^{\prime}\right), 43.7\left(\mathrm{CH}_{2}\right.$, $\left.\mathrm{C} 12,13^{\prime}\right), 106.8\left(\mathrm{C}_{\mathrm{py}}, \mathrm{C} 18^{\prime}\right), 113.0\left(\mathrm{C}_{\mathrm{py}}, \mathrm{C} 16^{\prime}\right), 124.3\left(\mathrm{C}_{\mathrm{py}}, \mathrm{C} 2^{\prime}\right)$, $137.3\left(\mathrm{C}_{\mathrm{q}}, \mathrm{C} 4^{\prime}\right), 145.6\left(\mathrm{C}_{\mathrm{py}} \mathrm{C} 1^{\prime}\right), 143.9\left(\mathrm{C}=\mathrm{N}, \mathrm{C} 8^{\prime}\right), 158.4\left(\mathrm{C}_{\mathrm{q}}\right.$, $\left.\mathrm{C} 15^{\prime}\right), 179.8\left(\mathrm{C}=\mathrm{S}, \mathrm{C} 10^{\prime}\right)$. Because of the small amount of second isomer, not all proton and carbon atoms could be assigned and no coupling constants were calculated. Crystals were obtained by slow evaporation of the mother liquor.

Synthesis of 2-(6,7-Dihydroquinolin-8(5H)-ylidene)hydrazine-1carbothioamide (COTI- $\mathrm{NH}_{2}$ ). This compound was synthesized by a procedure from ref $^{22}$ however, slightly modified to avoid column chromatography.

Hydrazinecarbothioamide ( $0.37 \mathrm{~g}, 4.0 \mathrm{mmol}, 1$ equiv) was suspended in isopropanol $(10 \mathrm{~mL})$ at $80^{\circ} \mathrm{C}$. Then, 6,7-dihydroquinoline-8-one $(0.59 \mathrm{~g}, 4.0 \mathrm{mmol}, 1$ equiv $)$ was added, and the mixture was stirred under reflux for $5 \mathrm{~h}$. A pale-yellow solid was formed, which was filtered off, washed with cold isopropanol, and dried in vacuum. Yield: $0.65 \mathrm{~g}(74 \%)$. Elemental analysis: Calcd. for $\mathrm{C}_{10} \mathrm{H}_{12} \mathrm{~N}_{4} \mathrm{~S}$ (\%): C, 54.52; H, 5.49; N, 25.43; S, 14.55. Found (\%): C, 54.53; H, 5.48; N, 25.35; S, 14.59. MS in ACN/MeOH $+1 \% \mathrm{H}_{2} \mathrm{O}$ (positive): $\mathrm{m} / z$ 243.0675, $[\mathrm{HL}+\mathrm{Na}]^{+} .{ }^{1} \mathrm{H}$ NMR $\left(600 \mathrm{MHz}\right.$, DMSO- $d_{6}$; for the numbering scheme see Figure S9): $\delta=1.93$ (quint, ${ }^{3} J=6.2 \mathrm{~Hz}, 2 \mathrm{H}$, $\left.\mathrm{CH}_{2}, \mathrm{H} 6\right), 2.69\left(\mathrm{~m}, 2 \mathrm{H}, \mathrm{CH}_{2}, \mathrm{H} 7\right), 2.91\left(\mathrm{t},{ }^{3} \mathrm{~J}=6.0 \mathrm{~Hz}, 2 \mathrm{H}, \mathrm{CH}_{2}\right.$, $\mathrm{H} 5), 7.47\left(\mathrm{dd},{ }^{3} \mathrm{~J}=4.7 \mathrm{~Hz},{ }^{3} \mathrm{~J}=7.7\right.$. Hz, $\left.1 \mathrm{H}, \mathrm{CH}_{\mathrm{py}}, \mathrm{H} 2\right), 7.85$ (dd, ${ }^{3} \mathrm{~J}=$ $\left.7.8 \mathrm{~Hz},{ }^{4} \mathrm{~J}=1.5 \mathrm{~Hz}, 1 \mathrm{H}, \mathrm{CH}_{\mathrm{py}}, \mathrm{H} 3\right), 7.96\left(\mathrm{~s}, 1 \mathrm{H}, \mathrm{NH}_{2}, \mathrm{~N} 4\right), 8.37$ (s, $\left.1 \mathrm{H}, \mathrm{NH}_{2}, \mathrm{~N} 4\right), 8.61\left(\mathrm{dd},{ }^{4} J=1.5 \mathrm{~Hz},{ }^{3} \mathrm{~J}=4.8 \mathrm{~Hz}, 1 \mathrm{H}, \mathrm{CH}_{\mathrm{py}}, \mathrm{H1}\right)$, 14.28 (s, $1 \mathrm{H}, \mathrm{NH}, \mathrm{N} 3) .{ }^{13} \mathrm{C}$ NMR $\left(151 \mathrm{MHz}, \mathrm{DMSO}-d_{6}\right): \delta=22.2$ $\left(\mathrm{CH}_{2}, \mathrm{C} 6\right), 28.9\left(\mathrm{CH}_{2}, \mathrm{C} 5\right), 33.4\left(\mathrm{CH}_{2}, \mathrm{C} 7\right), 124.4\left(\mathrm{C}_{\mathrm{py}}, \mathrm{C} 2\right), 137.7$ $\left(\mathrm{C}_{\mathrm{q}}, \mathrm{C} 4\right), 138.6\left(\mathrm{C}_{\mathrm{py}}, \mathrm{C} 3\right), 139.2(\mathrm{C}=\mathrm{N}, \mathrm{C} 8), 145.9\left(\mathrm{C}_{\mathrm{py}} \mathrm{C} 1\right), 148.7$ $\left(\mathrm{C}_{\mathrm{q}}, \mathrm{C} 9\right), 178.2(\mathrm{C}=\mathrm{S}, \mathrm{C} 10)$. No isomerization in DMSO solution was observed for this compound.

Synthesis of the Iron(III) Complex of COTI-2 (Fe-COTI-2). COTI-2 $(0.20 \mathrm{~g}, 0.54 \mathrm{mmol}, 2$ equiv) was suspended in methanol $(10 \mathrm{~mL})$ and stirred at $50{ }^{\circ} \mathrm{C}$. Next, a solution of iron(III) nitrate nonahydrate $(0.13 \mathrm{~g}, 0.30 \mathrm{mmol}, 1.1$ equiv) in methanol $(2 \mathrm{~mL})$ was added dropwise. A dark green solution was formed, which was stirred under reflux for $2 \mathrm{~h}$. The solvent volume was reduced by evaporation under reduced pressure, and the solution was cooled at $-20{ }^{\circ} \mathrm{C}$ overnight. On the next day, a dark brown-greenish solid was formed, which was filtered off, washed with cold methanol, and dried in vacuum. Yield: $37 \%$. Elemental analysis: Calcd. for $\left[\mathrm{Fe}\left(\mathrm{C}_{19} \mathrm{H}_{22} \mathrm{~N}_{6} \mathrm{~S}\right)_{2}\right]\left(\mathrm{NO}_{3}\right)_{3} \cdot 3 \mathrm{H}_{2} \mathrm{O}$ (\%): C, 44.36; H, 4.90; N, 20.42; S, 6.23. Found (\%): C, 44.61; H, 4.48; N, 20.08; S, 6.17. ESI-MS in $\mathrm{ACN} / \mathrm{MeOH}+1 \% \mathrm{H}_{2} \mathrm{O}$ (positive): $m / z$ 393.60, $[\mathrm{FeL}(\mathrm{HL})]^{2+} ; 786.24,\left[\mathrm{FeL}_{2}\right]^{+}$(Figure S10).

Synthesis of the Copper(II) Complex of COTI-2 (Cu-COTI-2). Copper(II) chloride dihydrate $(0.17 \mathrm{~g}, 1.0 \mathrm{mmol}, 1.1$ equiv) was dissolved in methanol $(10 \mathrm{~mL})$ at $40{ }^{\circ} \mathrm{C}$, and concentrated $\mathrm{HCl}(134$ $\mu \mathrm{L})$ was added. Next, a suspension of COTI-2 (0.30 g, $0.8 \mathrm{mmol}, 1$ equiv) was added dropwise to the copper(II) solution. A dark green solid was formed. The mixture was stirred for $2 \mathrm{~h}$, and the solid was filtered off, washed with cold methanol and diethyl ether, and dried in vacuum. Yield: $0.28 \mathrm{~g}$ (72\%). Elemental analysis: Calcd. for $\left[\mathrm{CuCl}_{2}\left(\mathrm{C}_{19} \mathrm{H}_{22} \mathrm{~N}_{6} \mathrm{~S}\right)\right]$ (\%): C, 45.56; H, 4.43; N, 16.78; S, 6.40 . Found (\%): C, 45.25; H, 4.41; N, 16.47; S, 6.14. ESI-MS in ACN/ $\mathrm{MeOH}+1 \% \mathrm{H}_{2} \mathrm{O}$ (positive): $m / z$ 428.09, $[\mathrm{CuL}]^{+}$; 464.05, $[\mathrm{Cu}-$ $(\mathrm{HL}) \mathrm{Cl}^{+} ; 891.07\left[\mathrm{Cu}_{2} \mathrm{~L}_{2} \mathrm{Cl}\right]^{+}$(Figure S11). The synthesis was repeated without $\mathrm{HCl}$, yielding the same complex. Green crystals were obtained by slow evaporation of the mother-liquor from both syntheses, with and without $\mathrm{HCl}$.

$X$-Ray Diffraction Analysis. The X-ray intensity data were measured on a Bruker D8 Venture diffractometer equipped with a multilayer monochromator, $\mathrm{MoK} \alpha$ for $\mathrm{COTI}-2$ and $\mathrm{CuK} \alpha$ for $\mathrm{Cu}-$ COTI-2, an INCOATEC micro focus sealed tube, and an Oxford cooling system. The structures were solved by direct methods. Nonhydrogen atoms were refined with anisotropic displacement parameters. Hydrogen atoms were inserted at calculated positions and refined with a riding model. The list of software used can be found in the Supporting information. Experimental data and CCDC-codes (available online at http://www.ccdc.cam.ac.uk/conts/retrieving. html) can be found in Table S1. Crystal data, data collection parameters, and structure refinement details are in Tables S2-S7.

Mass Spectroscopic Studies of the Reaction of CU-COTI-2 and GSH. A stock solution of Cu-COTI-2 (1 mM in DMF) was diluted $1: 1$ with an ammonia acetate buffer $(50 \mathrm{mM}, \mathrm{pH} 6.85)$. GSH was freshly dissolved in the same buffer and mixed 1:1 with the previously prepared $\mathrm{Cu}$-complex solution, resulting in an excess of GSH (3 equiv). The sample was kept at r.t. for $15 \mathrm{~min}$ and subsequently measured by mass spectroscopy using an amaZon speed ETD. For the reference measurement, the same solution without the addition of GSH was used.

Cell Culture. The following human cell lines and resistant sublines were used: the colon carcinoma cell line SW480 (from American Type Culture Collection, Manassas, VA), and the Triapine-resistant line SW480/Tria; ${ }^{24}$ the small cell lung carcinoma GLC-4, and its ABCC1-overexpressing adriamycin-resistant subline GLC-4/adr (from Dr. deVries, Groningen, The Netherlands). The ABC transporter expression levels of GLC-4/adr were assessed by Western blotting of membrane-enriched fractions. SW480 cells were grown in minimal essential medium with $10 \%$ fetal bovine serum (FBS), while GLC-4 cells were grown in RPMI-1640 with $10 \%$ FBS.

The newly established SW480/Coti-resistant cell line was generated by continuous exposure of SW480 cells to increasing concentrations of COTI-2 (starting point $250 \mathrm{nM}$, end point 1360 $\mathrm{nM}$ ) over a period of approximately one year. COTI-2 was administered to the cells once a week at the day after passage when cells had attached to the cell culture flasks.

Viability Assays. Cells were seeded $\left(2 \times 10^{4}\right.$ cells/well for SW480, SW480/Coti, GLC-4 and GLC-4/adr; $3 \times 10^{4}$ cells/well for SW480/ Tria) in $100 \mu \mathrm{L} /$ well in 96-well plates and allowed to attach for $24 \mathrm{~h}$ at $37{ }^{\circ} \mathrm{C}$ and $5 \% \mathrm{CO}_{2}$. Compounds were diluted in DMSO and then further diluted in a growth medium (DMSO concentration $<1 \%$ ). Drug dilutions were added in $100 \mu \mathrm{L} /$ well, with the final concentrations of $0,0.005,0.01,0.05,0.1,1,5,10$, and $20 \mu \mathrm{M}$, depending on the compound and cell line. For modulator studies, compounds were added in a $50 \mu \mathrm{L}$ growth medium and modulators (verapamil and CSA) in another $50 \mu \mathrm{L}$ medium. For glutathione synthesis inhibition, BSO was added $18 \mathrm{~h}$ before drug treatment. After drug treatment, cells were incubated for $72 \mathrm{~h}$ at $37^{\circ} \mathrm{C}$ and $5 \% \mathrm{CO}_{2}$. The proportion of viable cells was determined by 3-(4,5dimethylthiazole-2-yl)-2,5-diphenyltetrazolium assay (MTT) following the manufacturer's recommendations (EZ4U, Biomedica, Vienna, Austria). Anticancer activity was expressed as $\mathrm{IC}_{50}$ values (drug concentrations inducing 50\% reduction of cell survival in comparison to the control) calculated from full dose-response curves using GraphPad Prism software.

Growth Curve. Cells were seeded $\left(5 \times 10^{4}\right.$ cells $\left./ \mathrm{mL}\right)$ in $500 \mu \mathrm{L}$ in 12 -wells. After indicated incubation times at $37{ }^{\circ} \mathrm{C}$ and $5 \% \mathrm{CO}_{2}$, cells were trypsinized and counted. After every $24 \mathrm{~h}, 400 \mu \mathrm{L}$ of the growth medium was added to ensure sufficient growth stimulation. 
Western Blot Analysis. Protein lysates of membrane-enriched fractions were prepared, separated by SDS-PAGE (7.5\% and 10\% gels), and transferred onto a polyvinylidene difluoride membrane for Western blotting as described previously. ${ }^{16,17}$ The following primary antibodies were used: anti-ABCB1 monoclonal mouse C219 (Signet, Dedham, USA), dilution: 1:100; anti-ABCG2 monoclonal mouse MAB4146 (Chemicon, Temicola, USA), 1:500; anti-ABCC1 monoclonal mouse MON9017 (Synbio), 1:1000; anti-ABCC2 monoclonal mouse C250 (Alexis Corp., Lausen, Switzerland), 1:50; anti- $\beta$-actin monoclonal mouse AC-15 (Sigma Aldrich), 1:1000; antiGAPDH monoclonal rabbit D16H11 (Cell Signaling. Germany). Secondary, horseradish peroxidase-labeled antibodies that were antirabbit monoclonal mouse (sc-2357, Santa Cruz Biotechnology, Austria) and anti-mouse polyclonal goat (A0168, Merck, Germany) were used in working dilutions of 1:10,000.

Flow Cytometry. For cell death analysis, cells were stained with $\mathrm{AV} / \mathrm{PI}$, and for cell cycle analysis, cells were fixed and stained with PI, as previously described. ${ }^{10}$ Briefly, $2 \times 10^{5}$ SW480 or SW480/Coti cells/well were seeded in 6-wells and treated with $0.1,1$, and $10 \mu \mathrm{M}$ of COTI-2 for $24 \mathrm{~h}$. Then, cells were trypsinized and for cell death analysis stained with allophycocyanine (APC)-labelled AV (BD Biosciences) and PI $(0.01 \mathrm{mg} / \mathrm{mL}$, Sigma). For cell cycle analysis, collected cells were fixed in ice-cold $70 \%$ ethanol, treated with RNase $(0.2 \mathrm{mg} / \mathrm{mL}$, Sigma), and DNA was stained using PI. Stained cells were measured using a flow cytometry (FACS Calibur, Becton Dickinson, CA, USA) and analyzed using Cell Quest Pro software.

Cell Death Analysis by DAPI Staining. Cells were seeded $\left(2 \times 10^{5}\right.$ cells/well) in 6-wells and left to recover for $24 \mathrm{~h}$. Then, indicted treatment was added for $24 \mathrm{~h}$ after which cells were collected by trypsinization and transferred to microscopic slides by centrifugation with the cytocentrifuge Thermo Scientific Cytospin 4 (400 rpm, 5 min). After drying, cells were fixed on $-20{ }^{\circ} \mathrm{C}$ with a precooled methanol/aceton (1:1) mixture for $10 \mathrm{~min}$ and dyed with DAPI (1 $\mu \mathrm{g} / \mathrm{mL}$ ) for another $10 \mathrm{~min}$. For microscopy, cells were mounted with Vectashield (H-100, Vector Laboratories, Inc., CA, USA).

Microscopy. Cells were seeded $2 \times 20^{4}$ /well in 24-well plates and left to recover for $24 \mathrm{~h}$. Then, cells were treated with COTI- 2 with indicated concentrations. After $24 \mathrm{~h}$, microscopy images were taken with a Nikon eclipse Ti-e fluorescence microscope with differential interference contrast and a sCMOS pco.edge camera. Images were processed and analyzed by ImageJ. Cells with vacuoles were counted and given in percent of all attached cells. For immunofluorescence imaging of $A B C C 1$, cells were transferred to microscopy slides using a cytocentrifuge (Cytospin 4, Thermo Scientific, USA) at $400 \mathrm{rpm}$ for 5 min. After drying, the cells were fixed with $4 \%$ PFA for $15 \mathrm{~min}$ at room temperature and blocked with $20 \%$ fetal calf serum in PBS for $1 \mathrm{~h}$. Cells were stained with primary anti-ABCC1 monoclonal mouse MON9017 (Synbio) (1:50 in 1\% bovine serum albumin in PBS) and secondary anti-mouse conjugated to AlexaFluor488 (Thermo Fisher, $1: 200$ in $1 \%$ bovine serum albumin in PBS). After washing, counterstain was performed with DAPI $(1 \mu \mathrm{g} / \mathrm{mL})$ and wheat germ agglutinin (WGA) conjugated to Rhodamine $(10 \mu \mathrm{g} / \mathrm{mL}$, Vector Laboratories, USA) for $10 \mathrm{~min}$. Vectashield (H-100, Vector Laboratories, Inc., CA, USA) was used for mounting, and cells were imaged at the confocal Zeiss LSM 700 Olympus microscope (Carl Zeiss AG, Oberkochen, Germany) and processed with ImageJ.

Spectrophotometric Kinetic Measurements on the Reduction of the Copper(II) Complexes by GSH. The redox reaction of the copper(II) complexes of COTI-2, COTI- $\mathrm{NH}_{2}$, and Triapine with GSH was studied at $25.0 \pm 0.1{ }^{\circ} \mathrm{C}$ on an Agilent Cary 8454 diode array spectrophotometer using a special, tightly closed tandem cuvette (Hellma Tandem Cell, 238-QS). The reactants were separated until the reaction was triggered. Both isolated pockets of the cuvette were completely deoxygenated by bubbling a stream of argon for $10 \mathrm{~min}$ before mixing the reactants. Spectra were recorded before and then immediately after the mixing, and changes were followed until no further absorbance change was observed, and then $\mathrm{O}_{2}$ was passed through the samples. One of the isolated pockets contained GSH and its concentration was $9.0 \mathrm{mM}$, and the other contained the copper(II) complex at $30 \mu \mathrm{M}$ concentration. The copper(II) complex of COTI-2 was used directly, while the other complexes were prepared in situ by mixing the equimolar solutions of the metal ion and ligand. The $\mathrm{pH}$ of all the solutions was adjusted to 7.40 by $50 \mathrm{mM}$ HEPES buffer. The stock solutions of the reducing agent and complexes were freshly prepared every day.

\section{ASSOCIATED CONTENT}

\section{Supporting Information}

The Supporting Information is available free of charge at https://pubs.acs.org/doi/10.1021/acs.jmedchem.0c01277.

Scheme of the synthesis of COTI-2; overlay of crystal structures of $\mathrm{Cu}-\mathrm{COTI}-2 \mathrm{a} / \mathrm{b}$; concentration-response curves in SW480, SW480/Coti, and SW480/Tria cells; growth curves of SW480 and SW480/Coti cells; Western blot of short-term exposition of COTI-2 in SW480 cells; concentration-response curves in GLC-4 and GLC-4/adr cells; mass spectra of Cu-COTI-2 after incubation with GSH; UV-vis spectra of COTI-2 with GSH in HEPES vs RPMI1640; NMR numbering schemes for COTI-2 and COTI-NH ${ }_{2}$; mass spectra of Fe-COTI-2 and Cu-COTI-2; and details of X-ray data collection and refinement for COTI- 2 and Cu-COTI2a/b (PDF)

Molecular formula strings (CSV).

\section{AUTHOR INFORMATION}

\section{Corresponding Authors}

Petra Heffeter - Institute of Cancer Research, Medical University of Vienna, Vienna 1090, Austria; Research Cluster "Translational Cancer Therapy Research", Vienna 1090, Austria; Email: petra.heffeter@meduniwien.ac.at

Christian R. Kowol - Institute of Inorganic Chemistry, Faculty of Chemistry, University of Vienna, Vienna 1090, Austria; Research Cluster "Translational Cancer Therapy Research", Vienna 1090, Austria; (1) orcid.org/0000-00028311-1632; Email: christian.kowol@univie.ac.at

\section{Authors}

Julia H. Bormio Nunes - Institute of Inorganic Chemistry, Faculty of Chemistry, University of Vienna, Vienna 1090, Austria; Inorganic Chemistry Department, Institute of Chemistry, University of Campinas - UNICAMP, Campinas, São Paulo 13083-970, Brazil; ㅇorcid.org/0000-00018113-6679

Sonja Hager - Institute of Cancer Research, Medical University of Vienna, Vienna 1090, Austria; Research Cluster "Translational Cancer Therapy Research", Vienna 1090, Austria

Marlene Mathuber - Institute of Inorganic Chemistry, Faculty of Chemistry, University of Vienna, Vienna 1090, Austria

Vivien Pósa - Department of Inorganic and Analytical Chemistry, Interdisciplinary Excellence Centre and MTASZTE Lendület Functional Metal Complexes Research Group, University of Szeged, Szeged H-6720, Hungary

Alexander Roller - Institute of Inorganic Chemistry, Faculty of Chemistry, University of Vienna, Vienna 1090, Austria

Eva A. Enyedy - Department of Inorganic and Analytical Chemistry, Interdisciplinary Excellence Centre and MTASZTE Lendület Functional Metal Complexes Research Group, University of Szeged, Szeged H-6720, Hungary; (1) orcid.org/0000-0002-8058-8128

Alessia Stefanelli - Institute of Cancer Research, Medical University of Vienna, Vienna 1090, Austria 
Walter Berger - Institute of Cancer Research, Medical University of Vienna, Vienna 1090, Austria; Research Cluster "Translational Cancer Therapy Research", Vienna 1090, Austria; (1) orcid.org/0000-0003-0014-1658

Bernhard K. Keppler - Institute of Inorganic Chemistry, Faculty of Chemistry, University of Vienna, Vienna 1090, Austria; Research Cluster "Translational Cancer Therapy Research", Vienna 1090, Austria

Complete contact information is available at: https://pubs.acs.org/10.1021/acs.jmedchem.0c01277

\section{Author Contributions}

\#J.H.B.N. and S.H. contributed equally to the main findings of this manuscript.

\section{Notes}

The authors declare no competing financial interest.

${ }^{\nabla}$ P.H. and C.R.K. have shared last authorship.

\section{ACKNOWLEDGMENTS}

This work was supported by the Austrian Science Fund (FWF) grant P31923 (to C.R.K. and P.H.). J.H.B.N. would like to thank Österreichischer Austauschdienst (OeAD) for her Ernst Mach Grant-worldwide. Furthermore, we thank the bilateral OeAD project HU 02/2020. A.S. was employed by the DocFunds project "International $\mathrm{PhD}$ program translational oncology" (IPPTO) by the FWF, and S.H. was funded by the DOC Fellowship of the Austrian Academy of Sciences. This work was supported by National Research, Development and Innovation Office-NKFIA through project FK 124240 and Ministry of Human Capacities, Hungary grant, TKP-2020. We thank Jennifer Hsu for establishing the COTI-resistant SW480/Coti cells.

\section{ABBREVIATIONS LIST}

$\mathrm{ABC}$, ATP-binding cassette; ABCB1 (=P-gp), ATP-binding cassette transporter $\mathrm{B} 1$; ABCC1 (=MRP1), ATP-binding cassette transporter $\mathrm{C} 1$; $\mathrm{ABCC} 2$, ATP-binding cassette transporter $\mathrm{C} 2$; ABCG2, ATP-binding cassette transporter G2; ACN, acetonitrile; APC, allophycocyanine; AV, annexin $\mathrm{V}$; BSO, buthionine sulfoximine; COTI-2, 4-(pyridine-2-yl)- $\mathrm{N}$ ([(8E)-5,6,7,8-tetrahydroquinolin-8-ylidene ]amino)piperazine-1-carbothioamide; CSA, cyclosporine A; DAPI, 4',6-diamidin-2-phenylindol; DFO, desferrioxamine; DMF, dimethylformamide; DMSO, dimethyl sulfoxide; Dp, di-2pyridyl; Dp44mT, di-2-pyridylketone-4,4-dimethyl-3-thiosemicarbazone; DpC, di-2-pyridylketone 4-cyclohexyl-4-methyl-3thiosemicarbazone; ESI, electrospray ionization; FBS, fetal bovine serum; GADPH, glycerinaldehyd-3-phosphat-dehydrogenase; GSH, glutathione; HEPES, 2-[4-(2-hydroxyethyl)piperazin-1-yl] ethanesulfonic acid; MDR, multidrug resistance; $\mathrm{MeOH}$, methanol; MRP1 (=ABCC1), multidrug resistance protein 1; MS, mass spectrometry; MTT, 3-(4,5-dimethylthiazol-2-yl)-2,5-diphenyltetrazolium bromide; NMR, nuclear magnetic resonance; PBS, phosphate buffered saline; PFA, paraformaldehyde; PI, propidium iodide; PTSC, pyridine-2carboxaldehyde $N^{4}, N^{4}$-dimethyl-thiosemicarbazone; P-gp, Pglycoprotein; SD, standard deviation; SDS-PAGE, sodium dodecyl sulfate polyacrylamide gel electrophoresis; TSC, thiosemicarbazone; UV, ultraviolet; UV-vis, UV-visible; WGA, wheat germ agglutinin

\section{REFERENCES}

(1) Lobana, T. S.; Sharma, R; Bawa, G.; Khanna, S. Bonding and structure trends of thiosemicarbazone derivatives of metals-An overview. Coord. Chem. Rev. 2009, 253, 977-1055.

(2) Beraldo, H.; Gambino, D. The wide pharmacological versatility of semicarbazones, thiosemicarba-zones and their metal complexes. Mini-Rev. Med. Chem. 2004, 4, 31.

(3) Yu, Y.; Kalinowski, D. S.; Kovacevic, Z.; Siafakas, A. R.; Jansson, P. J.; Stefani, C.; Lovejoy, D. B.; Sharpe, P. C.; Bernhardt, P. V.; Richardson, D. R. Thiosemicarbazones from the old to new: Iron chelators that are more than just ribonucleotide reductase inhibitors. J. Med. Chem. 2009, 52, 5271-5294.

(4) Heffeter, P.; Pape, V. F. S.; Enyedy, E. A.; Keppler, B. K.; Szakacs, G.; Kowol, C. R. Anticancer thiosemicarbazones: chemical properties, interaction with iron metabolism, and resistance development. Antioxid. Redox Signaling 2019, 30, 1062-1082.

(5) Lovejoy, D. B.; Jansson, P. J.; Brunk, U. T.; Wong, J.; Ponka, P.; Richardson, D. R. Antitumor Activity of Metal-Chelating Compound Dp44mT Is Mediated by Formation of a Redox-Active Copper Complex That Accumulates in Lysosomes. Cancer Res. 2011, 71, 5871-5880.

(6) Hager, S.; Pape, V. F. S.; Pósa, V.; Montsch, B.; Uhlik, L.; Szakács, G.; Tóth, S.; Jabronka, N.; Keppler, B. K.; Kowol, C. R.; Enyedy, E. A.; Heffeter, P. High copper complex stability and slow reduction kinetics as key parameters for improved activity, paraptosis induction and impact on drug-resistant cells of anticancer thiosemicarbazones. Antioxid. Redox Signaling 2020, 33, 395-414.

(7) Miah, A. B.; Harrington, K. J.; Nutting, C. M. Triapine in clinical practice. Eur. J. Clin. Med. Oncol. 2010, 2, 1-6.

(8) Kowol, C. R.; Trondl, R.; Heffeter, P.; Arion, V. B.; Jakupec, M. A.; Roller, A.; Galanski, M.; Berger, W.; Keppler, B. K. Impact of Metal Coordination on Cytotoxicity of 3-Aminopyridine-2-carboxaldehyde Thiosemicarbazone (Triapine) and Novel Insights into Terminal Dimethylation. J. Med. Chem. 2009, 52, 5032-5043.

(9) Kowol, C. R.; Miklos, W.; Pfaff, S.; Hager, S.; Kallus, S.; Pelivan, K.; Kubanik, M.; Enyedy, É. A.; Berger, W.; Heffeter, P.; Keppler, B. $\mathrm{K}$. Impact of Stepwise $\mathrm{NH}_{2}$-Methylation of Triapine on the Physicochemical Properties, Anticancer Activity, and Resistance Circumvention. J. Med. Chem. 2016, 59, 6739-6752.

(10) Hager, S.; Korbula, K.; Bielec, B.; Grusch, M.; Pirker, C.; Schosserer, M.; Liendl, L.; Lang, M.; Grillari, J.; Nowikovsky, K.; Pape, V. F. S.; Mohr, T.; Szakács, G.; Keppler, B. K.; Berger, W.; Kowol, C. R.; Heffeter, P. The thiosemicarbazone $\mathrm{Me}_{2} \mathrm{NNMe}_{2}$ induces paraptosis by disrupting the ER thiol redox homeostasis based on protein disulfide isomerase inhibition. Cell Death Dis. 2018, 9, 1052.

(11) Guo, Z.-L.; Richardson, D. R.; Kalinowski, D. S.; Kovacevic, Z.; Tan-Un, K. C.; Chan, G. C.-F. The novel thiosemicarbazone, di-2pyridylketone 4-cyclohexyl-4-methyl-3-thiosemicarbazone (DpC), inhibits neuroblastoma growth in vitro and in vivo via multiple mechanisms. J. Hematol. Oncol. 2016, 9, 98.

(12) Seebacher, N. A.; Richardson, D. R.; Jansson, P. J. A mechanism for overcoming P-glycoprotein-mediated drug resistance: novel combination therapy that releases stored doxorubicin from lysosomes via lysosomal permeabilization using Dp44mT or DpC. Cell Death Dis. 2016, 7, e2510-e2510.

(13) Salim, K. Y.; Maleki Vareki, S.; Danter, W. R.; Koropatnick, J. COTI-2, a new anticancer drug currently under clinical investigation, targets mutant p53 and negatively modulates the PI3K/AKT/mTOR pathway. Eur. J. Cancer 2016, 69, S19.

(14) Lindemann, A.; Patel, A. A.; Tang, L.; Liu, Z.; Wang, L.; Silver, N. L.; Tanaka, N.; Rao, X.; Takahashi, H.; Maduka, N. K.; Zhao, M.; Chen, T.-C.; Liu, W.; Gao, M.; Wang, J.; Frank, S. J.; Hittelman, W. N.; Mills, G. B.; Myers, J. N.; Osman, A. A. COTI-2, a novel thiosemicarbazone derivative, exhibits antitumor activity in HNSCC through p53-dependent and -independent mechanisms. Clin. Cancer Res. 2019, 25, 5650-5662.

(15) Salim, K. Y.; Vareki, S. M.; Danter, W. R.; Koropatnick, J. COTI-2, a novel small molecule that is active against multiple human 
cancer cell lines in vitro and in vivo. Oncotarget 2016, 7, 4136341379.

(16) Miklos, W.; Pelivan, K.; Kowol, C. R.; Pirker, C.; Dornetshuber-Fleiss, R.; Spitzwieser, M.; Englinger, B.; van Schoonhoven, S.; Cichna-Markl, M.; Koellensperger, G.; Keppler, B. K.; Berger, W.; Heffeter, P. Triapine-mediated ABCB1 induction via PKC induces widespread therapy unresponsiveness but is not underlying acquired triapine resistance. Cancer Lett. 2015, 361, $112-120$.

(17) Heffeter, P.; Pirker, C.; Kowol, C. R.; Herrman, G.; Dornetshuber, R.; Miklos, W.; Jungwirth, U.; Koellensperger, G.; Keppler, B. K.; Berger, W. Impact of terminal dimethylation on the resistance profile of $\alpha$-N-heterocyclic thiosemicarbazones. Biochem. Pharmacol. 2012, 83, 1623-1633.

(18) Robey, R. W.; Pluchino, K. M.; Hall, M. D.; Fojo, A. T.; Bates, S. E.; Gottesman, M. M. Revisiting the role of $\mathrm{ABC}$ transporters in multidrug-resistant cancer. Nat. Rev. Cancer 2018, 18, 452-464.

(19) Wiese, M.; Stefan, S. M. The A-B-C of small-molecule ABC transport protein modulators: From inhibition to activation-a case study of multidrug resistance-associated protein 1 (ABCC1). Med. Res. Rev. 2019, 39, 2031-2081.

(20) Cole, S. P. C.; Deeley, R. G. Transport of glutathione and glutathione conjugates by MRP1. Trends Pharmacol. Sci. 2006, 27, 438-446.

(21) Danter, W. R.; Brown, M.; Lepifre, F. Compounds and method for treatment of cancer. Patent US8034815B2. 2011.

(22) Lemke, T. L.; Shek, T. W.; Cates, L. A.; Smith, L. K.; Cosby, L. A.; Sartorelli, A. C. Synthesis of 5,6-dihydro-8(7H)-quinolinone thiosemicarbazones as potential antitumor agents. J. Med. Chem. 1977, 20, 1351-1354.

(23) Kowol, C. R.; Eichinger, R.; Jakupec, M. A.; Galanski, M.; Arion, V. B.; Keppler, B. K. Effect of metal ion complexation and chalcogen donor identity on the antiproliferative activity of 2acetylpyridine $\mathrm{N}, \mathrm{N}$-dimethyl(chalcogen)semicarbazones. J. Inorg. Biochem. 2007, 101, 1946-1957.

(24) Pessôa, M. M. B.; Andrade, G. F. S.; Paoli Monteiro, V. R.; Temperini, M. L. A. 2-Formylpyridinethiosemicarbazone and methyl derivatives: Spectroscopic studies. Polyhedron 2001, 20, 3133-3141.

(25) ChemAxon Instant J Chem/MarvinSketch; ChemAxon Ltd.: Budapest, Hungary, 2012.

(26) Richardson, D. R.; Sharpe, P. C.; Lovejoy, D. B.; Senaratne, D.; Kalinowski, D. S.; Islam, M.; Bernhardt, P. V. Dipyridyl Thiosemicarbazone Chelators with Potent and Selective Antitumor Activity Form Iron Complexes with Redox Activity. J. Med. Chem. 2006, 49, 6510-6521.

(27) Kowol, C. R.; Berger, R.; Eichinger, R.; Roller, A.; Jakupec, M. A.; Schmidt, P. P.; Arion, V. B.; Keppler, B. K. Gallium(III) and Iron(III) Complexes of $\alpha$-N-Heterocyclic Thiosemicarbazones: Synthesis, Characterization, Cytotoxicity, and Interaction with Ribonucleotide Reductase. J. Med. Chem. 2007, 50, 1254-1265.

(28) Kowol, C. R.; Heffeter, P.; Miklos, W.; Gille, L.; Trondl, R.; Cappellacci, L.; Berger, W.; Keppler, B. K. Mechanisms underlying reductant-induced reactive oxygen species formation by anticancer copper(II) compounds. J. Biol. Inorg. Chem. 2012, 17, 409-423.

(29) Korp, J. D.; Bernal, I.; Lemke, T. L. Crystal and molecular structure of $(Z)-5,6$-dihydro-8 $(7 H)$ quinolinone thiosemicarbazone. J. Cryst. Mol. Struct. 1978, 8, 115-126.

(30) Joseph, M.; Kuriakose, M.; Kurup, M. R. P.; Suresh, E.; Kishore, A.; Bhat, S. G. Structural, antimicrobial and spectral studies of copper(II) complexes of 2-benzoylpyridine N(4)-phenyl thiosemicarbazone. Polyhedron 2006, 25, 61-70.

(31) Beshir, A. B.; Guchhait, S. K.; Gascón, J. A.; Fenteany, G. Synthesis and structure-activity relationships of metal-ligand complexes that potently inhibit cell migration. Bioorg. Med. Chem. Lett. 2008, 18, 498-504.

(32) Saswati; Chakraborty, A.; Dash, S. P.; Panda, A. K.; Acharyya, R.; Biswas, A.; Mukhopadhyay, S.; Bhutia, S. K.; Crochet, A.; Patil, Y. P.; Nethaji, M.; Dinda, R. Synthesis, X-ray structure and in vitro cytotoxicity studies of $\mathrm{Cu}(\mathrm{I} / \mathrm{II})$ complexes of thiosemicarbazone: special emphasis on their interactions with DNA. Dalton Trans. 2015, 44, 6140-6157.

(33) Miklos, W.; Heffeter, P.; Pirker, C.; Hager, S.; Kowol, C. R.; van Schoonhoven, S.; Stojanovic, M.; Keppler, B. K.; Berger, W. Loss of phosphodiesterase 4D mediates acquired triapine resistance via Epac-Rap1-Integrin signaling. Oncotarget 2016, 7, 84556-84574.

(34) Maleki Vareki, S.; Salim, K. Y.; Danter, W. R.; Koropatnick, J. Novel anti-cancer drug COTI-2 synergizes with therapeutic agents and does not induce resistance or exhibit cross-resistance in human cancer cell lines. PLoS One 2018, 13, 1-17.

(35) Yuan, J.; Lovejoy, D. B.; Richardson, D. R. Novel di-2-pyridylderived iron chelators with marked and selective antitumor activity: in vitro and in vivo assessment. Blood 2004, 104, 1450-1458.

(36) Trondl, R.; Flocke, L. S.; Kowol, C. R.; Heffeter, P.; Jungwirth, U.; Mair, G. E.; Steinborn, R.; Enyedy, É. A.; Jakupec, M. A.; Berger, W.; Keppler, B. K. Triapine and a More Potent Dimethyl Derivative Induce Endoplasmatic Reticulum Stress in Cancer Cells. Mol. Pharmaceutics 2014, 85, 451-459.

(37) Cserepes, M.; Türk, D.; Tóth, S.; Pape, V. F. S.; Gaál, A.; Gera, M.; Szabó, J. E.; Kucsma, N.; Várady, G.; Vértessy, B. G.; Streli, C.; Szabó, P. T.; Tovari, J.; Szoboszlai, N.; Szakács, G. Unshielding Multidrug Resistant Cancer through Selective Iron Depletion of PGlycoprotein-Expressing Cells. Cancer Res. 2020, 80, 663-674.

(38) Jansson, P. J.; Sharpe, P. C.; Bernhardt, P. V.; Richardson, D. R. Novel Thiosemicarbazones of the ApT and DpT Series and Their Copper Complexes: Identification of Pronounced Redox Activity and Characterization of Their Antitumor Activity. J. Med. Chem. 2010, 53, 5759-5769.

(39) Park, K. C.; Fouani, L.; Jansson, P. J.; Wooi, D.; Sahni, S.; Lane, D. J. R.; Palanimuthu, D.; Lok, H. C.; Kovaĉević, Z.; Huang, M. L. H.; Kalinowski, D. S.; Richardson, D. R. Copper and conquer: copper complexes of di-2-pyridylketone thiosemicarbazones as novel anticancer therapeutics. Metallomics 2016, 8, 874-886.

(40) Ishiguro, K.; Lin, Z. P.; Penketh, P. G.; Shyam, K.; Zhu, R.; Baumann, R. P.; Zhu, Y.-L.; Sartorelli, A. C.; Rutherford, T. J.; Ratner, E. S. Distinct mechanisms of cell-kill by triapine and its terminally dimethylated derivative $\mathrm{Dp} 44 \mathrm{mT}$ due to a loss or gain of activity of their copper(II) complexes. Biochem. Pharmacol. 2014, 91, 312-322.

(41) Drew, R.; Miners, J. O. The effects of buthionine sulphoximine (BSO) on glutathione depletion and xenobiotic biotransformation. Biochem. Pharmacol. 1984, 33, 2989-2994.

(42) Santoro, A.; Calvo, J. S.; Peris-Díaz, M. D.; Krężel, A.; Meloni, G.; Faller, P. The Glutathione/Metallothionein System Challenges the Design of Efficient $\mathrm{O}_{2}$-Activating Copper Complexes. Am. Ethnol. 2020, 132, 7904-7909.

(43) Santoro, A.; Vileno, B.; Palacios, Ò.; Peris-Díaz, M. D.; Riegel, G.; Gaiddon, C.; Kręel, A.; Faller, P. Reactivity of Cu (ii)-, Zn (ii)and $\mathrm{Fe}$ (ii)-thiosemicarbazone complexes with glutathione and metallothionein: from stability to dissociation to transmetallation. Metallomics 2019, 11, 994-1004.

(44) Kalinowski, D. S.; Stefani, C.; Toyokuni, S.; Ganz, T.; Anderson, G. J.; Subramaniam, N. V.; Trinder, D.; Olynyk, J. K.; Chua, A.; Jansson, P. J.; Sahni, S.; Lane, D. J. R.; Merlot, A. M.; Kovacevic, Z.; Huang, M. L. H.; Lee, C. S.; Richardson, D. R. Redox cycling metals: Pedaling their roles in metabolism and their use in the development of novel therapeutics. Biochim. Biophys. Acta, Mol. Cell Res. 2016, 1863, 727-748. 